\title{
Adaptive capacity: from assessment to action in coastal social-ecological systems
}

\author{
Charlotte K. Whitney ${ }^{1}$, Nathan J. Bennett ${ }^{2,3,4}$, Natalie C. Ban $^{1}$, Edward H. Allison $^{2}$, Derek Armitage ${ }^{5}$, Jessica L. Blythe ${ }^{6,7}$, Jenn M. \\ Burt $^{8,9}$, William Cheung $^{10}, \underline{\text { Elena M. Finkbeiner }}^{4,11}$, Maery Kaplan-Hallam ${ }^{3}, \underline{\text { Ian Perry }}^{12}$, Nancy J. Turner $^{1}$ and Lilia Yumagulova $^{13}$
}

\begin{abstract}
Because of the complexity and speed of environmental, climatic, and socio-political change in coastal marine socialecological systems, there is significant academic and applied interest in assessing and fostering the adaptive capacity of coastal communities. Adaptive capacity refers to the latent ability of a system to respond proactively and positively to stressors or opportunities. A variety of qualitative, quantitative, and participatory approaches have been developed and applied to understand and assess adaptive capacity, each with different benefits, drawbacks, insights, and implications. Drawing on case studies of coastal communities from around the globe, we describe and compare 11 approaches that are often used to study adaptive capacity of social and ecological systems in the face of social, environmental, and climatic change. We synthesize lessons from a series of case studies to present important considerations to frame research and to choose an assessment approach, key challenges to analyze adaptive capacity in linked socialecological systems, and good practices to link results to action to foster adaptive capacity. We suggest that more attention be given to integrated social-ecological assessments and that greater effort be placed on evaluation and monitoring of adaptive capacity over time and across scales. Overall, although sustainability science holds a promise of providing solutions to real world problems, we found that too few assessments seem to lead to tangible outcomes or actions to foster adaptive capacity in social-ecological systems.
\end{abstract}

Key Words: adaptation; adaptive capacity; climate change; coastal communities; resilience; social-ecological systems

\section{INTRODUCTION}

Coastal communities are experiencing complex social and ecological changes at multiple scales and speeds (Steffen et al. 2011, Kareiva and Marvier 2012, Kueffer and Kaiser-Bunbury 2014, Moore 2016). The oceans are severely affected by humaninduced global environmental change, with warming and acidifying waters, changing currents, and declining fish stocks that simultaneously drive related impacts on coastal ecosystems and human communities (Harley et al. 2006, Worm et al. 2006, Johnson et al. 2011). Economic globalization and markets can also drive changes in demands for certain marine species, pressure on resources, migration to coastal communities, and changes in nearshore vessel traffic (e.g., Tuler et al. 2008, Bennett et al. 2016a). Both biophysical and social drivers of change are presenting as risks or opportunities in coastal social-ecological systems (Adger et al. 2005b, Sales 2009), making it especially relevant to understand whether communities are able to adapt (Gallopín 2006, Cinner et al. 2012, Bennett et al. 2014, 2016a). Assessments of adaptive capacity, i.e., "the ability of systems, institutions, humans, and other organisms to adjust to potential damage, take advantage of opportunities, or to respond to the consequences" (IPCC 2014:118), can provide such an understanding (Armitage and Plummer 2010, Mcleod et al. 2016).

Along with vulnerability analysis, assessments of adaptive capacity are often used to provide the basis for planning adaptations or management actions to mitigate impacts in efforts to achieve beneficial social or ecological outcomes (McClanahan et al. 2008, Marshall et al. 2010, Hill and Engle 2013). These assessments tend to draw either from theories of ecological resilience (Holling 1973) or social resilience (Adger 2000, Folke et al. 2002, Engle 2011). In natural systems, ecological adaptive capacity is an indicator of evolutionary adaptive potential, suggesting that a species or ecosystem has the existing natural ability to persist over time and through change (Dobzhansky 1968, Smit and Wandel 2006). In contrast, the adaptive capacity of social systems refers to the ability of human actors and communities to respond to change and maintain human wellbeing over time (Smit and Wandel 2006). Numerous qualitative, quantitative, and participatory approaches have been developed to analyze adaptive capacity, each giving varying levels of attention to different components of the social or ecological system. As a result, each approach to assessing adaptive capacity produces different results, insights, and recommendations. However, there have been few comparative reviews of the different adaptive capacity assessment approaches that contrast their relative measures, outcomes, and applications (Gupta et al. 2010, Engle 2011, Fabinyi et al. 2014).

Given today's global challenges, an important objective of adaptive capacity assessments, indeed of all sustainability science, is to foster positive real-world action that improves the ability of a given system to adapt to change (Kates et al. 2001, Wiek et al.

\footnotetext{
${ }^{1}$ School of Environmental Studies, University of Victoria, ${ }^{2}$ School of Marine and Environmental Affairs, University of Washington, ${ }^{3}$ Institute for Resources, Environment and Sustainability, University of British Columbia, ${ }^{4}$ Center for Ocean Solutions, Stanford University, ${ }^{5}$ University of Waterloo, ${ }_{6}^{6}$ Australian Research Council Centre of Excellence for Coral Reef Studies, James Cook University, ${ }^{7}$ WorldFish, ${ }^{8}$ School of Resource and Environmental Management, Simon Fraser University, ${ }^{9}$ Hakai Institute, ${ }^{10}$ Institute for the Oceans and Fisheries, University of British Columbia, ${ }^{11}$ Hopkins Marine Station, Stanford University, ${ }^{12}$ Pacific Biological Station, Fisheries \& Oceans Canada, ${ }^{13}$ School for Community and Regional Planning, University of British Columbia
} 
2012, Glandon 2015). However, it is generally unclear the extent to which previous efforts to measure or characterize adaptive capacity have led to on-the-ground actions to increase adaptive capacity. Furthermore, disparate assessment methodologies produce dissimilar descriptions of system properties and can lead to identification of different and even divergent interventions. By describing, clarifying, and contextualizing a diversity of assessment methods, we aim to improve the consistency and quality of adaptive capacity assessments. Here, we examine the strengths and drawbacks of 11 approaches for evaluating adaptive capacity, with a particular focus on coastal communities as linked social-ecological systems (SESs). Coastal communities are at significant risk from the cumulative effects of anthropogenic change and coastal development to climate change and they also support a large proportion of the world's human population (Hallegatte et al. 2013, Weatherdon et al. 2016a). As such, measuring and fostering the adaptive capacities of coastal socialecological systems is of particular importance for researchers, planners, and policy makers (Wong et al. 2014). We identify the insights and implications of employing each approach and propose some best practices for selecting and applying different adaptive capacity techniques. We also provide a conceptual framework that links adaptive capacity assessments to management and planning actions to foster adaptive capacity across both social and ecological systems.

\section{OVERVIEW OF APPROACHES TO ASSESS ADAPTIVE CAPACITY}

The variety of ways in which adaptive capacity is defined, applied, assessed, and measured reflect a diversity of interests, areas of expertise, and theoretical rationales (Table 1). As with the application of resilience theory, understanding the adaptive capacity "of what to what" helps to frame an appropriate assessment approach as well as the corresponding actions or interventions (Fabinyi et al. 2014). Although the diversity of adaptive capacity assessment tools might be useful in different contexts, the multitude of different definitions and ways of conceiving of the problem can be unclear. This complexity and lack of conceptual clarity may increase the likelihood that an approach to assess adaptive capacity is not chosen mindfully, which is problematic given that the recommendations stemming from assessments may have real consequences for SESs.

Our aim is to provide direction to adaptive capacity assessments so as to foster and improve proactive interventions. Based on a literature review of adaptive capacity studies using key word search terms (adaptive capacity, adaptation, vulnerability, coastal communities, social-ecological systems) in Google Scholar and Web of Science for papers published between 1990 and 2015, we identified adaptive capacity assessment approaches that spanned a range of scales from local to large scale and also varied in their emphasis on social or ecological methods. We were particularly interested in research that was framed with a SESs lens. The approaches were grouped into 11 categories based on differences in methods, scale of application, and social or ecological focus: (1) large-scale social indicators, (2) large-scale ecological indicators and models, (3) integrated social-ecological indicators, (4) governance approaches, (5) multiple community surveys, (6) social experiments, (7) species-level experiments, (8) historical ethnographic approaches, (9) participatory planning approaches, (10) qualitative community-based approaches, and (11) mixed- method approaches (Table 1, Appendix 1). This list covers broad categories of adaptive capacity analyses to illustrate the range of possible approaches and may not be comprehensive. Although these approaches are described as distinct for the purposes of clarity, we acknowledge that in many cases, approaches could be taken that combine aspects of several of these tools.

We held a workshop in November 2015 with 12 academic researchers who had experience (as reflected in their publication and implementation experience) in adaptive capacity research across these categories in coastal SESs. The workshop served as an opportunity to guide discussion and provide expert opinion on the diversity of ways in which the concept of adaptive capacity is applied. The group was convened to explore the following overarching questions: What are the strengths, drawbacks, and insights of the range of approaches for analyzing adaptive capacity? How might these different approaches be applied to analyze the adaptive capacity of linked SESs? What lessons can be learned from previous efforts to bridge analyses of adaptive capacity with taking actions to build adaptive capacity? For each identified approach to assess adaptive capacity, one participant was asked to present and prepare a brief synopsis based on the following criteria:

1. Describe the approach used to analyze adaptive capacity.

2. What type(s) of indicators were used?

3. At what scale was the approach applied?

4. What are the main strengths and benefits of the approach?

5. What are the main weaknesses and drawbacks of choosing this approach?

6. What insights and related practical solutions emerged from using the approach?

7. To what extent did the approach engage with and link to both the social and ecological components of the system?

8. Does the approach take a past, present, or future orientation to understand adaptive capacity?

9. How have or how can the results be integrated into decision making?

10. What are the implications for communities of using each approach (e.g., of the process, outcomes, outputs, or recommendations)?

11. What key references best reflect this approach to analyzing adaptive capacity?

Using these questions as a framework, we compared and contrasted the different approaches (see Appendix 1 for more details). To illustrate the different approaches, we drew on our own case studies and examples from the literature. Rather than simply describe each approach (summarized in Table 1), we aimed to illuminate parallels and opportunities for developing better and more integrated assessments of adaptive capacity that incorporate indicators of both social and ecological change and associated risks and that link knowledge to action. This guiding comparison of the 11 approaches was directed by five key considerations: (1) attention to social or ecological systems, (2) spatial scale, (3) temporal scale and orientation, (4) social or ecological indicators, and (5) implications and outcomes to clarify 
Table 1. Summary of approaches used to measure and assess adaptive capacity of social, ecological, and social-ecological systems. Assessment approaches are listed in order of typical spatial scale of application from largest to smallest. See Appendix 1 for a detailed description of these approaches with references to example empirical studies and reviews.

\begin{tabular}{|c|c|c|c|c|}
\hline $\begin{array}{l}\text { Approach (social- } \\
\text { ecological system } \\
\text { focus) }\end{array}$ & Description & Strengths & Drawbacks & Methods and types of indicators \\
\hline $\begin{array}{l}\text { Large-scale social } \\
\text { indicators }\end{array}$ & $\begin{array}{l}\text { Cross-regional comparisons based } \\
\text { on defined indicators of social } \\
\text { adaptive capacities or } \\
\text { vulnerabilities }\end{array}$ & $\begin{array}{l}\text { Policy relevant; useful for describing } \\
\text { relative differences across regions or } \\
\text { communities }\end{array}$ & $\begin{array}{l}\text { Generic; relative composite } \\
\text { estimates; difficult to incorporate } \\
\text { local knowledge and perspectives; } \\
\text { relative measures can be difficult } \\
\text { to apply to policies for building } \\
\text { adaptive capacity }\end{array}$ & $\begin{array}{l}\text { Relative measures of adaptive } \\
\text { capacity across regions using } \\
\text { additive indicators of social } \\
\text { adaptive capacity, including risk } \\
\text { exposure, sensitivity, social assets, } \\
\text { wealth, learning, capital, } \\
\text { livelihoods, and others }\end{array}$ \\
\hline $\begin{array}{l}\text { Large-scale ecological } \\
\text { indicators and models }\end{array}$ & $\begin{array}{l}\text { Large-scale modeling of } \\
\text { ecological indicators to } \\
\text { understand species and ecosystem }\end{array}$ & $\begin{array}{l}\text { Understand large-scale patterns of } \\
\text { adaptive responses across multiple } \\
\text { species; useful application in }\end{array}$ & $\begin{array}{l}\text { Data intensive; coarse resolution } \\
\text { because of limitations of data; } \\
\text { uncertainty in modeled }\end{array}$ & $\begin{array}{l}\text { Modeling based on fisheries catch } \\
\text { data, species distributions, } \\
\text { oceanographic data }\end{array}$ \\
\hline
\end{tabular}

Integrated socialecological indicators

Uses integrated social-ecological understanding to gain a systemsbased understanding of adaptive capacity

Governance

approaches

Multiple community surveys

Social experiments

Species-level experiments

Historical ethnographic approaches

Participatory planning approaches

Qualitative community-based approaches

Mixed-method approaches

Literature review combined with community-based engagement is used to build understanding of governance institutions and processes

Survey or interview methods capacities among multiple communities or across regions that give insight to decisionmaking behaviors of fishers or other stakeholders

Experimental assessments of the

Oral history, interviews, and literature are used to understand how past adaptations of communities or households may relate to present or future adaptive capacities Risk assessment and community planning are used to address resilience of communities or regions to change

Inductive methods are used to within a single community

Combined methods are used to provide a comparison of adaptive detecting change for fisheries; can inform species management Policy relevant; examines both social and ecological drivers of change and their interdependencies projection

Data intensive; outcomes are relative measures; difficult to apply to local communities for management applications

Explores the role and context of governance arrangements and decision-making processes in facilitating adaptive actions

Limited to processes, not mechanisms or contexts of change; inadequate attention to the nature of change

Generates qualitative understanding Community engagement is time

Behavioral economic experiments adaptive potential of populations and species to a particular stressor understand the adaptive capacities qualitative understanding relationships based on understand and compare diversity communities, sectors, or regions and flexibility of communities enables comparison and leverage points of cultural, historical, and realized adaptive actions; can identify perceived barriers to adaptation community based; builds understanding of self-perceived adaptive capacity Gives nuanced understanding of identification of weaknesses and strengths, generic or common

consuming; interpretation and interview bias; may address responses more than mechanisms; link to specific stressors not always evident

Experimental approach is controlled Community engagement is time mechanisms of behavior unless combined with other tools (interviews or surveys) Focus on single (or few) specific traits; often cannot account for natural variability or interacting factors; often limited to single lifehistory stage; subject to sample size and logistic constraints Community engagement is time consuming, requires social networks and trust; not scalable; adaptations that occurred in response, with links made to present

Comprehensive utility-based pt changes and adaptations may not be relevant in the present

Community engagement is time consuming; requires community buy-in or knowing the gatekeepers

Community engagement is time consuming; requires community buy-in and acceptance; results are context specific and may not be applicable to other communities

Community engagement is time consuming; expensive; difficult to surveys, focus groups, participatory confirm the recommendations and methods, policy analysis, literature outcomes across multiple communities tolerance limits, genetic variation;
Relative measures of adaptive capacity using indicators that integrate social and ecological dimensions of change in regions or communities; example framework is the I-ADApT assessment tool Interviews, governance-specific attributes, and indicators; example frameworks are Institutional Analysis and Development and Interactive Governance Surveys and interviews across multiple communities using a range of social indicators

Choice experiments, economic experiments

Lab or field based experiments to evaluate phenotypic plasticity, common garden experiments; holding studies

Interviews, analyses of past records, community knowledge sharing

Combination of mixed methods: interviews, surveys, participant observation during planning events; participatory action research Interviews, focus groups, participant observation reviews 
Fig. 1. Comparison of 11 approaches for assessing adaptive capacity at different spatial scales and with varying attention to social and ecological systems.

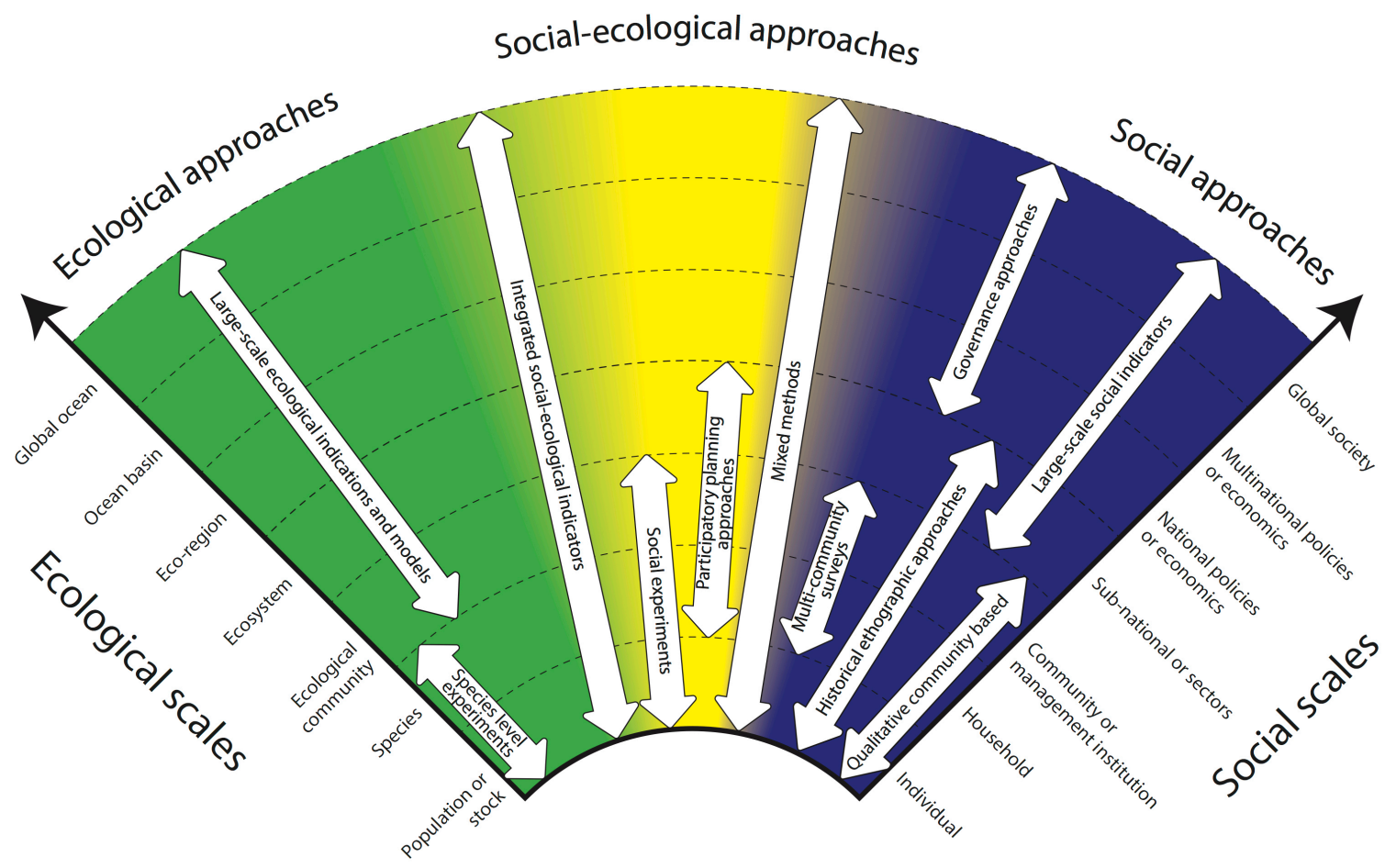

the trade-offs in choosing a particular approach to assess adaptive capacity in a particular context.

\section{Attention to social or ecological adaptive capacity}

Adaptive capacity assessments have tended to focus on either ecological or social adaptive capacity, with emerging approaches increasingly bridging social and ecological methods (Fig. 1). Ecological adaptive capacity can be assessed at a range of scales using field or laboratory experiments (species-level experiments; e.g., Crozier and Zabel 2006, Eliason et al. 2011, Whitney et al. 2013) or large-scale analyses and models of thermal tolerance, species traits, fisheries catches, biomass, ocean conditions, or market-based data on fisheries landings over time (large-scale ecological indicator approaches; Sunday et al. 2011, Cheung et al. 2015). Both small- and large-scale ecological assessments offer valuable information about adaptive capacities to disturbances such as climate change and increase the understanding of ecosystem responses to changes such as increasing temperatures. However, in isolation, the response or management applications of these empirical and model-based studies remain theoretical and without context to the appropriate or feasible policy changes and other responses that result in meaningful action. Social adaptive capacity assessments tend to focus on aspects of governance at different scales (e.g., local rules or actions, or federal macro policies) or on agency (of communities), norms and beliefs, the ability to predict and have foresight related to environmental conditions and change, occupational mobility and diversity, social capital and leadership, and the political and economic contexts for adaptive capacity (Armitage 2005, Folke et al. 2005). Reflecting the diversity of social-system components and the different social scales at which they can be applied, a broader range of approaches to assess social adaptive capacity have emerged (Fig. 1). Integrated social-ecological approaches consider a set of bridging adaptive capacity concepts that apply to both social and ecological systems or that incorporate the feedbacks and interactions between ecological and social systems by incorporating metrics of both. For example, when flexibility is assessed in both social and natural systems, it is possible to describe how social groups (e.g., fishers) respond to changes in natural conditions (e.g., fisheries abundance) as well as to changes in governance or other social structures (Blythe et al. 2014, Aguilera et al. 2015, Finkbeiner 2015).

\section{Spatial scale}

Adaptive capacity can be assessed at different interacting spatial scales using a range of scale-appropriate measures in either ecological or social systems (Adger et al. 2005a, Hill and Engle 2013; Fig. 1). Large-scale approaches based on large-scale ecological (Aguilera et al. 2015) or social indicators (e.g., Allison et al. 2009, Himes-Cornell and Kasperski 2015), ecological modeling-based studies (Cheung et al. 2015, Gattuso et al. 2015), and governance analyses (Dietz et al. 2003, Armitage and Plummer 2010, Gupta et al. 2010) provide rapid comparative results for policy decisions and, in some cases, may be operationalized more quickly than in-depth assessments at smaller scales. However, a limitation of large-scale studies is that they do not incorporate local, traditional, or cultural knowledge, address household or individual capacities, and, because of their large scale and coarse approach, often do not allow for local validation of results or vetting of recommendations. In contrast, community-based participatory methods can provide nuanced understanding of the dynamic nature of a group or community 
Fig. 2. Example measures of adaptive capacity in ecological or social systems across spatial scales. Measures are examples only and are not meant to be prescriptive or specific to a given scale as shown here.
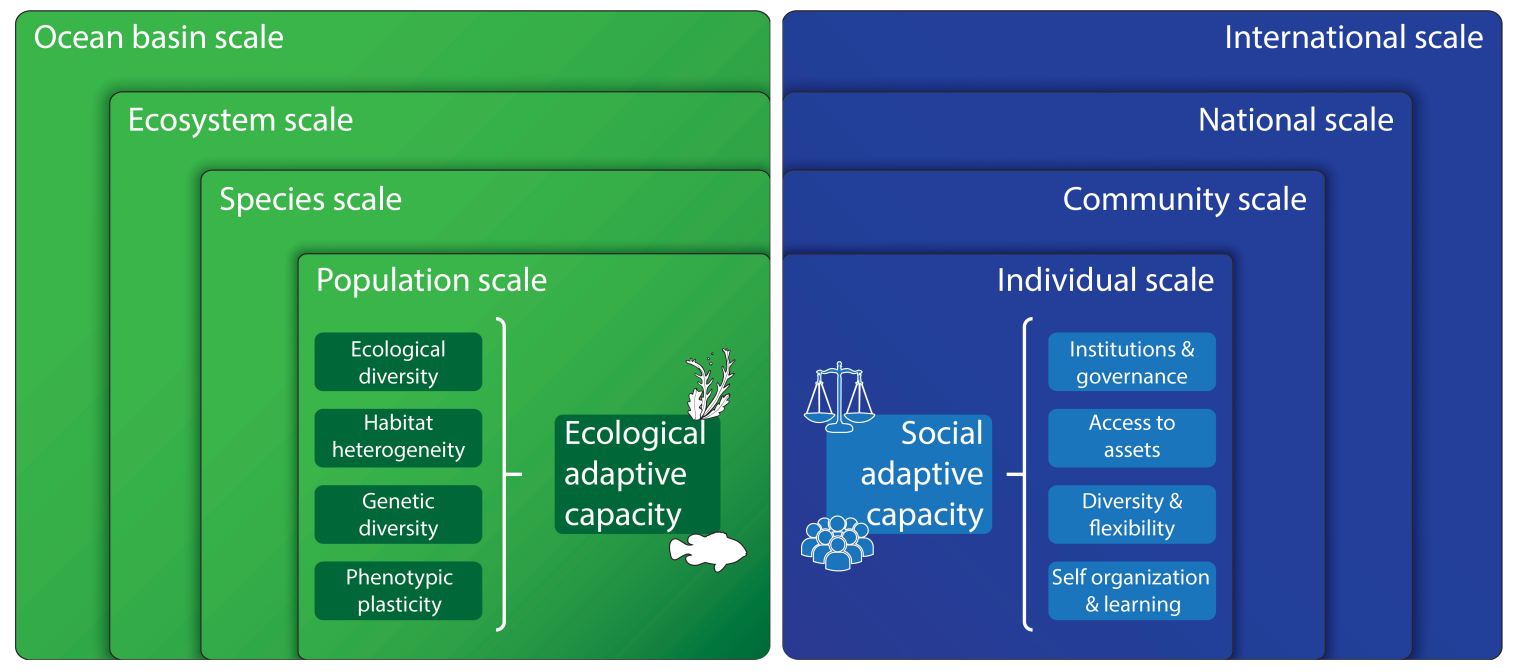

and its historical, present, and potential adaptive responses, as well as include the views and preferences of community and stakeholders (e.g., Henly-Shepard et al. 2015). Participatory methods may also integrate well with qualitative methods such as interviews and quantitative methods such as surveys in developing a deeper and more holistic understanding of household- to community-level adaptive capacities and strategies (Bennett et al. 2014, 2016a,b). However, action-research, community-based methods, and mixed-method approaches may require significant time commitments (e.g., years; decades for historical approaches) that exceed research program and funding time lines. Each approach to assessment has different strengths and weaknesses of which the researcher needs to be mindful.

\section{Temporal scale and orientation}

The measurement of adaptive capacity is generally for a given time period and based on available data and the selected indicators. Assessments of adaptive capacity can focus on shortterm time scales (measuring coping or acclimation potential) or over longer time scales (enabling social adaptation or evolutionary adaptation). In ecological systems, short-term adaptive strategies usually refer to acclimation to a new (or temporary) environmental state; acclimation may draw on phenotypic plasticity, habitat diversity, or short-term behavioral responses (Stillman 2003). If an environmental stressor or shift continues, long-term adaptive strategies depend on evolutionary responses at the species level or migration strategies (leaving the area for better suited habitats; Jensen et al. 2008, Chown et al. 2010, Ekstrom et al. 2015). Social communities may cope with change in the short term through social networks, informal arrangements, alternative income generating activities, or financial remittances from overseas family members (Adger 2003, Adger et al. 2007).

The temporal orientation of adaptive capacity assessments can also focus on learning from the past, examining the present, or predicting future response capacity. Rarely are assessments of adaptive capacity conducted over multiple time periods (although see Cinner et al. 2015), with the majority of assessment methods focusing on the recent past or present (Engle 2011). An exception to this is historical ethnographic methods, which focus specifically on how human communities have adapted to changing environmental conditions in the past, with insight for present or future adaptive capacities (Berkes and Jolly 2001, Turner and Clifton 2009, Blythe et al. 2014). Conversely, ecological modeling techniques (Cheung et al. 2009, 2010, Weatherdon et al. 2016b) or analyses of governance and institutions (Brooks et al. 2005) can apply scenario planning to assess future adaptive capacities (Peterson et al. 2003, Tompkins et al. 2008, Tschakert and Dietrich 2010, Oteros-Rozas et al. 2015, Bennett et al. 2016b). Future predictions of adaptive capacity are especially relevant for urban planning and disaster planning in coastal settings, where assessments can indicate important vulnerabilities for policy or management action (Adger et al. 2005b, Malakar 2013, HenlyShepard et al. 2015). Planning approaches to adaptive capacity include "participatory futures approaches" for community-based climate change adaptation, which engage and empower community members to be active collaborators in developing community scenarios that facilitate coevolutionary adaptation to climate change, rather than passive adaptation (Gidley et al. 2009).

\section{Indicators: social, ecological, or integrated}

We broadly categorize indicators that are commonly used for measuring the adaptive capacity of both social and ecological systems (Table 2, Fig. 2) in an effort to provide useful insights to guide policy and management improvements across scales (Armitage and Plummer 2010). Indicators can be quantitative measures of adaptability summarized as indices (Yohe and Tol 2002) or can comprise qualitative perceptions of individuals or communities about their capacity to adapt (Armitage and Plummer 2010, Hinkel 2011, Bennett 2016). Ecological indicators of adaptive capacity (Fig. 2) are based on diversity and flexibility across a range of traits (e.g., life history or behavioral) and organizational levels (e.g., genetic, species, populations) as well as access to and interactions with suitable habitats (Aitken et al. 2008, Mawdsley et al. 2009, Hutchings 2011, O'Connor et al. 2012, Benscoter et al. 2013). Social indicators of adaptive capacity (Fig. 
Table 2. Examples of generic social and ecological measures used in assessments of adaptive capacity. Many of these measures are operationalized as indicators in assessments.

\begin{tabular}{|c|c|c|}
\hline \multicolumn{2}{|r|}{ Characteristics of social adaptive capacity } & Characteristics of ecological adaptive capacity \\
\hline Category & Indicator & Category \\
\hline Diversity & $\begin{array}{l}\text { nd flexibility } \\
\text { Livelihood and income diversity } \\
\text { Economic opportunities } \\
\text { Level of dependence on natural resources } \\
\text { Occupational mobility } \\
\text { Place attachment } \\
\text { Migration patterns } \\
\text { Willingness to change }\end{array}$ & $\begin{array}{l}\text { Diversity and flexibility } \\
\text { Species diversity } \\
\text { Genetic diversity } \\
\text { Functional redundancy across species } \\
\text { Response diversity across species } \\
\text { Species' life history traits (e.g., metabolic rates, size, reproductive } \\
\text { strategies such as generation time, fecundity) } \\
\text { Broad habitat range and tolerance }\end{array}$ \\
\hline Access to & $\begin{array}{l}\text { ssets } \\
\text { Household material assets (e.g., boats, gear) } \\
\text { Community infrastructure } \\
\text { Levels of education } \\
\text { Financial status and access to sources of credit } \\
\text { Access to markets } \\
\text { Bridging social capital and institutional supports } \\
\text { Natural capital } \\
\text { Equity, rights, and access to resources } \\
\text { Cultural memory, traditions, and assets }\end{array}$ & $\begin{array}{l}\text { Habitats and interactions } \\
\qquad \begin{array}{l}\text { Habitat availability } \\
\text { Habitat heterogeneity } \\
\text { Habitat connectivity (opportunity) } \\
\text { Rate and magnitude of habitat disturbance } \\
\text { Habitat diversity } \\
\text { Phenology }\end{array}\end{array}$ \\
\hline Learning & $\begin{array}{l}\text { nd knowledge } \\
\text { Resource monitoring and feedback mechanisms } \\
\text { Knowledge of disturbance (e.g., climate change) } \\
\text { Perceptions of risk } \\
\text { Spaces and platforms for learning } \\
\text { Diversity of knowledge and information sources } \\
\text { Ability to anticipate change } \\
\text { Recognition of causality and human agency } \\
\text { Intergenerational learning capacity }\end{array}$ & $\begin{array}{l}\text { Capacity to adapt within species } \\
\text { Behavioral change (e.g., prey switching) and learning } \\
\text { Phenotypic plasticity } \\
\text { Tolerance limits } \\
\text { Rapid genetic adaptation of traits through behavior change and } \\
\text { acclimation } \\
\text { Reproductive rate and capacity for dissemination } \\
\text { Dispersal capacity } \\
\text { Migration capacity }\end{array}$ \\
\hline Governan & $\begin{array}{l}\text { e and institutions } \\
\text { Levels of trust, social capital, and networks } \\
\text { Gender and race relations } \\
\text { Levels of participation and quality of decision-making processes } \\
\text { Planning capacity } \\
\text { Presence of local environmental institutions and strength of social } \\
\text { norms } \\
\text { Quality of governance and leadership in environmental policies and } \\
\text { agencies } \\
\text { Accountability of managers and governance bodies } \\
\text { Active risk management and adaptive governance processes }\end{array}$ & $\begin{array}{l}\text { Self-organizing systems } \\
\text { Community structure and dynamics }\end{array}$ \\
\hline
\end{tabular}

2) can be grouped into four broad categories: access to assets, diversity and flexibility, learning and knowledge, and governance and institutions (Adger 2003, Brooks et al. 2005, Allison et al. 2009, Hinkel 2011, Bennett et al. 2014). Some indicators of social and ecological adaptive capacity complement each other (e.g., diversity, flexibility, modularity, access to assets or habitats), whereas others do not have an ecological equivalent (e.g., social capital, innovation, institutional structures, governance strategies; Walker and Salt 2006, Nemec et al. 2013; Table 2). An important distinction between social and natural systems is that humans have agency and foresight, theoretically leading to learning and proactive decision-making power, whereas natural systems and species assemblages generally do not have agency or foresight (Walker et al. 2002, except in some indigenous world views; Kimmerer 2013, Turner 2014).

Implications and applications of adaptive capacity approaches If applied to the same case study, each of the 11 approaches highlighted here would reveal varied insights and produce very different recommendations for policy or management. For example, an assessment of the ecological adaptive capacity of a commercially valuable fish species might suggest that managers restrict harvesting or target particular stocks with higher adaptive capacity (e.g., Pacific salmon; Whitney et al. 2013). In contrast, assessments of social adaptive capacity of the same fishing community might recommend gear restrictions, livelihood diversification programs, or basic service provision support to assist the human community dependent on that fishery. Thus, choosing any one approach inevitably involves the prioritization of different actions and potential trade-offs such as different scales of analysis and insights, levels of attention to social and ecological systems, temporal orientation, as well as methods and indicators (Table 1). The approach chosen will also be driven by the objectives and skills of the researcher or research team. Overall, one consistent weakness across all methods included here is the lack of direct connection between assessments and actions taken to augment adaptive capacity. To select the most relevant and effective approach, it is important to be mindful of the many 
choices to be made prior to assessment as well as the good practices for evaluating and building adaptive capacity.

\section{SYNTHESIS OF LESSONS LEARNED}

Drawing on our review, we present: (1) a set of considerations for framing the problem and choosing an appropriate assessment approach, (2) key challenges that require attention when analyzing adaptive capacity in SESs, and (3) good practices for linking results to action to foster adaptive capacity (Table 3 ).

\section{Framing adaptive capacity research: choosing an assessment approach}

Adaptive capacity assessments are commonly limited by a lack of clarity on the assumptions and contextual outcomes of a particular method or a lack of attention to the applicability of an assessment tool to the context, scale, or stressor under consideration (Adger and Vincent 2005, Engle 2011). These barriers limit the accuracy of the relative estimates of adaptive capacity and the applicability of results when seeking to identify policy solutions and thus diminish the potential for implementing proactive measures for fostering adaptive capacity within and among systems. Some approaches can contribute to more than one of these goals. Being clear and transparent about the purpose and mindful of methods will strengthen the analysis. To address these challenges, we highlight seven key questions to ask when selecting an assessment approach (Table 3), which include: the adaptive capacity of what, to what, of whom, and for whom; the scale and orientation of adaptive capacity; the types of indicators and methods that are available and relevant; and the purpose of the analysis. By highlighting these framing questions, as well as key challenges and good practices, the intention is that adaptive capacity assessments can become more transparent and intentional, and the results more applicable.

The adaptive capacity of a SES is inherently normative and scale dependent: The assessed adaptive capacity of an ecosystem or social community could be interpreted differently from the eyes of a policy analyst, facilitator, or stakeholder because each of these people has a different perception of the system and stressor (s) in question (Adger 2003, Cote and Nightingale 2012, Bennett 2016). The spatial scale of assessment is selected by the analyst and influences the results and recommendations of the assessment. Temporal scale also matters. Indicators of adaptive capacity reveal effects and responses over both slow and fast temporal scales. Building adaptive capacity of either social or ecological components of a system will also affect certain groups more than others. If the effect or change continues, coastal communities will need to develop long-term adaptive strategies that may be more dependent on governance, planning, infrastructure, adaptive management, sense of place, or even emigration (retreat) from factors such as rising sea levels (Tol et al. 2006, Adger et al. 2007, Berman et al. 2012, Joakim et al. 2015).

\section{Evaluating adaptive capacity: influential factors and key challenges}

Following the framing of an adaptive capacity assessment approach, there are several key considerations or challenges of which researchers and practitioners should be cognizant during their evaluation. Different groups or individuals can be politically marginalized or more vulnerable, leading to differential adaptive capacities (Tschakert 2007, Bunce et al. 2010). The perspectives and worldviews of researchers, stakeholders, governance agents, and change agents will doubtlessly affect the assessment and any actions to build adaptive capacity. Tools such as the SESs framework may help to understand the diversity of perspectives within a SES and the interactions therein (Basurto et al. 2013, McGinnis and Ostrom 2014). Depending on the timeline of assessment, certain tools may offer deep understanding yet be too expensive or time consuming (e.g., qualitative community engagement), whereas other tools may offer comparability across systems (e.g., large-scale index-based approaches). Ongoing evaluations of adaptive capacity are important to understand how response capacity changes over time. Adaptive capacity assessments are frequently a single project for a particular system and stressor, resulting in estimates that are quickly outdated and likely fail to connect with postassessment action (although this is rarely evaluated). Monitoring how adaptive capacity may change as the system reacts to change may allow a deeper understanding of feedbacks, trade-offs, and potential improvements to techniques for assessing and building adaptive capacity (see Cinner et al. 2015). We stress that postassessment evaluation should be a component of many adaptive capacity studies rather than single nonrepeated assessments. Although integrating across social and ecological components of a system can be beneficial, it is not always applicable in adaptive capacity studies. The IMBER-ADApT tool is a valuable example of an integrated social-ecological adaptive capacity assessment framework (Bundy et al. 2015). In choosing an integrated SESs perspective, it is more likely that multiple key characteristics of adaptive capacity as well as important trade-offs and feedbacks will be incorporated, leading to more robust analyses.

\section{Fostering adaptive capacity: linking assessment to action}

Based on our research, experience, and review of the literature, assessments and studies of adaptive capacity are rarely effectively linked to policy change or actions that promote adaptive capacity, despite clear directives or calls to do just that. For example, only one of the assessment approaches we examined linked to action based on that assessment (participatory planning; Appendix 1). The importance of participation and knowledge cocreation for enhancing adaptive capacity has long been emphasized (Folke et al. 2002). Participatory vulnerability assessments can help identify adaptation strategies that are most feasible and practical in communities with a focus on current risks, allowing for integration with resource management, disaster preparedness, and sustainable development initiatives (Smit and Wandel 2006). At the community level, linking assessments with actions may mean supporting forums for sharing knowledge within and across generations (social learning; Berkes and Jolly 2001, Pelling and High 2005). At the coastal community scale, this can mean supporting cross-generational knowledge-sharing platforms such as elder-youth groups, integrating harvesting trips among community members, or recording historical social norms that are relevant for the local ecological system (Senos et al. 2006, Turner 2014). At larger scales, linking assessment to evaluation and response offers researchers and managers the opportunity to learn from past mistakes and generate opportunities for fostering adaptive capacity (Perry et al. 2010). This might entail financial support mechanisms, government-led investments in jobs or other economic incentives, or educational platforms for community or regional leaders (Brooks et al. 2005, Bronen and Chapin 2013). 
Fig. 3. A conceptual framework to link adaptive capacity assessment to adaptive capacity building in socialecological systems. The adaptive capacity of the linked social-ecological system is first identified by assessing the level of ecological and social adaptive capacity (i.e., by conducting multiple or integrated assessments). With knowledge of the current state of the system, actions can be taken to build further adaptive capacity (e.g., improve ecological adaptive capacity) to move the system to a more desirable state. If considerations of tradeoffs are not included, the system's adaptive capacity could shift in focus without gains in total adaptive capacity (e.g., ecological adaptive capacity increases at the cost of decreasing social adaptive capacity). The model is based on similar schematics by McClanahan et al. (2008) and Ban et al. (2013); actions build on those suggested by Salafsky et al. (2008) and Cinner et al. (2012).

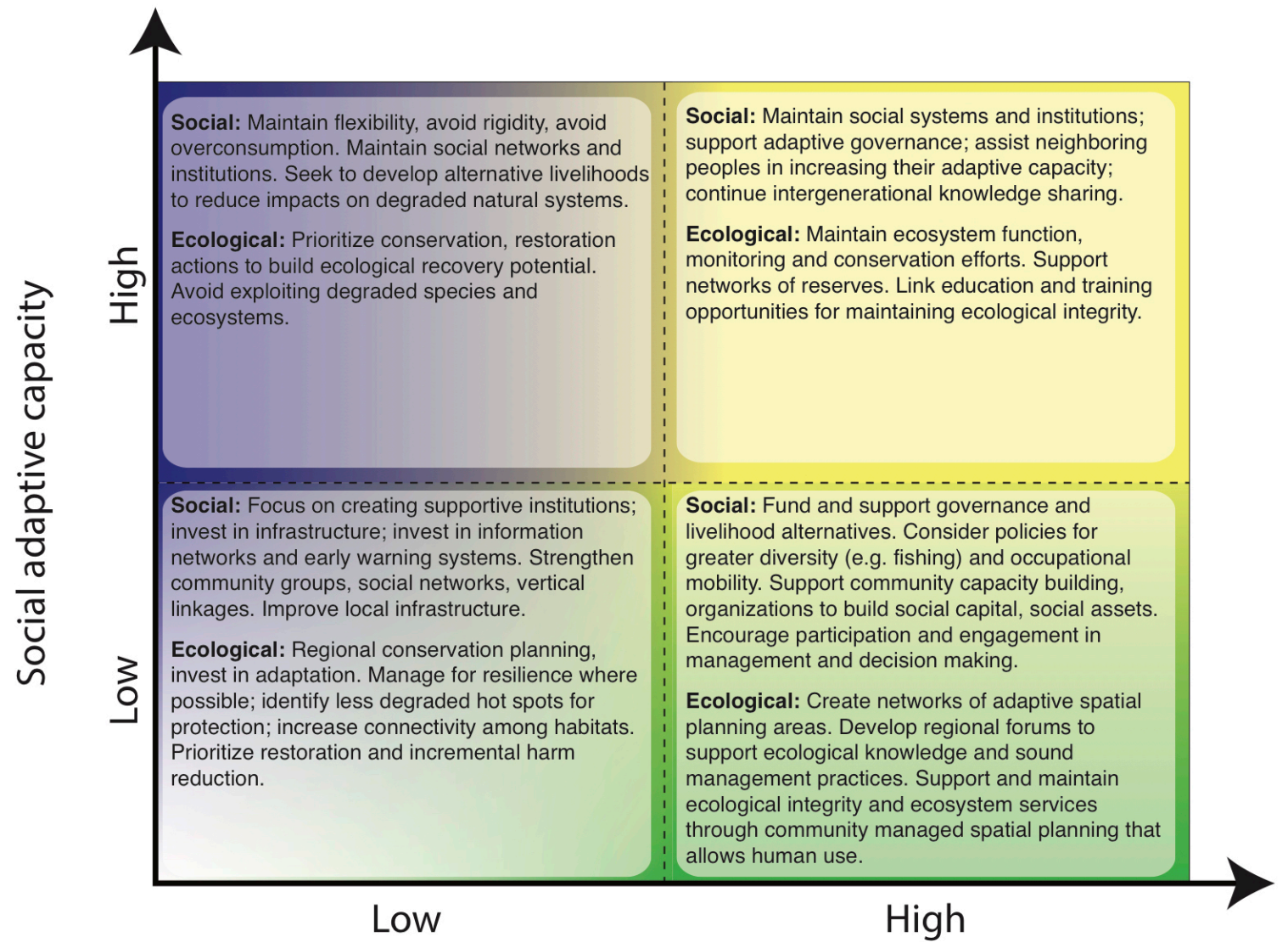

Ecological adaptive capacity

Building adaptive capacity through social learning can support the success of other related adaptive management opportunities, both within a project and across international processes (e.g., adaptive spatial planning; Mills et al. 2015).

Overall, it is increasingly important to shift from a reactive to a proactive framework for adaptive planning. For managers and policy makers, identifying the barriers to adaptation through evidence-based indices is valuable, especially across systems and at regional scales. For coastal communities and managers, considering the linked nature of SESs could lead to sustainable policies that support both social adaptive capacity factors as well as the adaptive capacity of the ecosystem. Considering the adaptive capacity of both social and ecological systems together can help to avoid social-ecological traps (Carpenter and Brock 2008, Cinner 2011). Although there are commonalities across assessment tools and conceptual models of what makes up high adaptive capacity for both social and ecological systems (e.g., diversity, redundancy, capital), indicators cannot truly be integrated for practical applied analyses (Nemec et al. 2013). It is, however, useful to consider social and ecological indicators of adaptive capacity as additive metrics that cumulatively characterize an integrated SES as having high or low adaptive capacity to a specific impact.

We propose a conceptual framework with which to prioritize potential actions based on integrated social-ecological adaptive capacity assessments (Fig. 3), building on themes proposed by McClanahan et al. (2008). In four quadrants, we illustrate example systems in which ecological and social adaptive capacity ranges from high to low, and we identify example actions that could foster adaptive capacity in either the social or ecological 
Table 3. Key considerations for operationalizing adaptive capacity research and practice.

\begin{tabular}{|c|c|c|}
\hline Stage of research or application & Considerations & Explanation and examples \\
\hline \multirow{7}{*}{$\begin{array}{l}\text { Framing the research: key } \\
\text { questions and considerations } \\
\text { when choosing an adaptive } \\
\text { capacity assessment approach }\end{array}$} & Adaptive capacity of what? & Systems: social, ecological, or both \\
\hline & Adaptive capacity to what? & Ecological: population(s), species, communities, ecosystem(s) \\
\hline & $\begin{array}{l}\text { Adaptive capacity of whom and } \\
\text { for whom? }\end{array}$ & $\begin{array}{l}\text { Social: individuals, households, communities, nations, governance systems, organizations, } \\
\text { policies, politics, infrastructure, economic industries, sectors }\end{array}$ \\
\hline & At what scale? & Single exposures: e.g., climate change or governance change \\
\hline & At what orientation? & Multiple exposures: e.g., climatic, environmental, governance, economic, and social combined \\
\hline & $\begin{array}{l}\text { What types of indicators and } \\
\text { methods? }\end{array}$ & Rate of change: rapid onset acute (discrete) shocks, continuous (chronic) exposures, or both \\
\hline & $\begin{array}{l}\text { What is the purpose of the } \\
\text { analysis? }\end{array}$ & Impact: stressors, opportunities, or both \\
\hline \multirow{9}{*}{$\begin{array}{l}\text { Evaluating adaptive capacity: } \\
\text { general factors and challenges } \\
\text { to take into account when } \\
\text { engaging in integrated adaptive } \\
\text { capacity assessment in coastal } \\
\text { social-ecological systems }\end{array}$} & Equity and access & $\begin{array}{l}\text { Groups and individuals have differing levels of vulnerability and adaptive capacity; pay attention } \\
\text { to: social differentiation, marginalization, politics and power dynamics, inclusion of diverse } \\
\text { voices and perspectives }\end{array}$ \\
\hline & $\begin{array}{l}\text { Diverse worldviews, knowledge, } \\
\text { and perspectives }\end{array}$ & $\begin{array}{l}\text { Different worldviews: e.g., western ecological science, social science theories, local knowledge; be } \\
\text { cognizant of the biases and assumptions therein }\end{array}$ \\
\hline & $\begin{array}{l}\text { Cumulative effects of multiple } \\
\text { exposures }\end{array}$ & $\begin{array}{l}\text { Ecological: e.g., increasing storm severity, ocean acidification, biodiversity loss; Social: e.g., } \\
\text { coastal development, population growth, economic crisis; changes can present as stressors or } \\
\text { opportunities in systems and can be additive, mitigative, or multiplicative }\end{array}$ \\
\hline & Change and complexity & $\begin{array}{l}\text { Change is constant and systems are dynamic; links among system components and feedbacks } \\
\text { cause complex and unpredictable changes in exposure and adaptive capacity }\end{array}$ \\
\hline & Social-ecological interactions & $\begin{array}{l}\text { Consider both social and ecological components of linked systems; consider adaptive and coping } \\
\text { responses of both ecological and social communities and systems within an integrated assessment } \\
\text { framework; prioritize actions that are holistic, benefiting both human well-being and ecological } \\
\text { integrity }\end{array}$ \\
\hline & Scalar interactions & $\begin{array}{l}\text { Scales of adaptive capacity are not independent; evaluate interactions between components of } \\
\text { adaptive capacity at higher and lower scales }\end{array}$ \\
\hline & Trade-offs in responses & $\begin{array}{l}\text { Feedbacks between adaptive responses: e.g., amplifying or diminishing effects on coastal } \\
\text { resources resulting from behavioral changes; identify and analyze trade-offs in ecological } \\
\text { management or social planning; incorporate decision-making tools and planning techniques that } \\
\text { account for trade-offs into adaptive capacity analyses }\end{array}$ \\
\hline & Be proactive, not reactive & $\begin{array}{l}\text { Anticipate known and unknown disturbances and identify opportunities for increasing adaptive } \\
\text { capacity in advance; reflect on potential unintended consequences of actions to build adaptive } \\
\text { capacity; expand planning for specific stressors (e.g., sea level rise) to include possible effects from } \\
\text { unexpected shocks (e.g., earthquakes, tsunamis) }\end{array}$ \\
\hline & $\begin{array}{l}\text { Limits and barriers to adaptive } \\
\text { capacity }\end{array}$ & $\begin{array}{l}\text { Stressors may overwhelm the adaptive capacity of social-ecological systems; certain factors, be } \\
\text { they ecological, technical, social, cultural, or political, can also undermine abilities of systems to } \\
\text { adapt; recognition of limits and barriers is an essential part of assessing adaptive capacity and } \\
\text { identifying actions }\end{array}$ \\
\hline \multirow{6}{*}{$\begin{array}{l}\text { Fostering adaptive capacity: } \\
\text { good practices for bridging } \\
\text { adaptive capacity assessments } \\
\text { with action outcomes }\end{array}$} & Learn by doing and adapt & $\begin{array}{l}\text { Encourage and integrate cycles of action with observation, reflection, learning, and revision (i.e., } \\
\text { adaptive management) }\end{array}$ \\
\hline & $\begin{array}{l}\text { Collaboration and coproduction of } \\
\text { knowledge }\end{array}$ & $\begin{array}{l}\text { Build teams that include: researchers, practitioners, policy makers, community leaders, and } \\
\text { implicated stakeholder groups; seek coidentification of problem; collaborative processes of } \\
\text { knowledge gathering and integration and the coproduction of tools to manage the problem }\end{array}$ \\
\hline & Shared learning & $\begin{array}{l}\text { Promote knowledge sharing and social learning within and among communities and across } \\
\text { generations; create opportunities and knowledge sharing platforms and or meetings to facilitate } \\
\text { knowledge exchange (e.g., community exchanges) }\end{array}$ \\
\hline & $\begin{array}{l}\text { Promote networks and social } \\
\text { capital }\end{array}$ & $\begin{array}{l}\text { Strong networks and social capital across families, communities, and nations can strengthen } \\
\text { adaptive capacity and enable the uptake and implementation of recommendations; risks and } \\
\text { impacts are lessened when there are others from outside who can help }\end{array}$ \\
\hline & Build capacity across scales & $\begin{array}{l}\text { Work with local communities or leaders in the implementation of recommendations to strengthen } \\
\text { local capacity to assess and respond to stressors and change; ensure that actions are being taken } \\
\text { at higher scales to support local capacity-building efforts }\end{array}$ \\
\hline & Communicate results & $\begin{array}{l}\text { Results of adaptive capacity assessments analysis need to be communicated to those implicated } \\
\text { (e.g., communities, resource users, etc.) and key decision makers, including managers and policy } \\
\text { makers; information needs to be presented in various formats }\end{array}$ \\
\hline
\end{tabular}

realm to move the system toward a state where both capacities are increased. If an assessment indicates that social or ecological adaptive capacity is low, we suggest potential actions that are designed to build capacity. If an assessment indicates that adaptive capacity is already high, we suggest actions that are intended to support existing capacity against future shocks or disturbances. The suggested actions are meant to be illustrative, not prescriptive, and the appropriate actions taken will depend on the social and ecological contexts. The actions are also not meant to be exclusive, and in some cases, multiple actions across scales will be possible or necessary.

\section{LIMITATIONS IN BRIDGING ASSESSMENTS TO ACTION}

Suggesting a set of potential actions to build adaptive capacity (Fig. 3) demands some important caveats. First, important tradeoffs exist between and across scales and across social and ecological systems (Walker et al. 2009). For example, building social adaptive capacity might involve diversifying or intensifying fisheries, for example, which could have the effect of decreasing biodiversity, abundance, and ecological adaptive capacities in that system (Coulthard 2012). Similarly, national-level policy changes to decrease fossil fuel production according to international 
agreements may negatively affect local economies, for example, by limiting fishing activity, at least in the short term (Biggs et al. 2012). Likewise, there may be temporal trade-offs whereby actions to build short-term adaptive capacity might imply a trade-off for future outcomes if those actions create barriers for future options. It is important to foster adaptive capacity that allows a SES to cope with change while not losing adaptive options for the future (Folke et al. 2002, Armitage and Plummer 2010). Moreover, we recognize the existence of taboo trade-offs or choices between morally incommensurable values such as trade-offs between the conservation of a particular species and human health (Daw et al. 2015).

Second, we recognize that building adaptive capacity requires situated research that is sensitive to particular contexts. The development of a universal framework for adaptive capacity is neither realistic nor desirable. For example, advocacy for institutional criteria (such as flexibility, diversity, legitimacy) can lead to highly differentiated and unpredictable effects on the ground. Rather, principles for assessing and building adaptive capacity must be drawn out of the specifics of each case where unique social-ecological processes and social relations of power are observable (Cote and Nightingale 2012). However, reluctance to simplify complex phenomena into useable metrics can result in their gradual omission from research and practice. That which cannot be measured can disappear from public debates and political consciousness. Conversely, indictors or metrics allow the definition of what is important, the measurement of change, and direct research and investment (Hicks et al. 2016). Therefore, this framework is intended as a starting point for developing more targeted and context-specific actions that build adaptive capacity in coastal SESs.

\section{CONCLUSIONS AND FUTURE DIRECTIONS}

The extent and speed of global change has catalyzed broad interest in understanding and supporting the capacity of SESs to respond to, cope with, and adapt to change. Adaptive capacity assessments that focus on climate change have been applied in many contexts, including forestry (Pramova et al. 2012), agriculture (Marshall et al. 2013, Wang et al. 2013), fisheries (Kalikoski et al. 2010, Cinner 2011, Cinner et al. 2013, Aguilera et al. 2015), conservation (McClanahan et al. 2008, Mcleod et al. 2016), and disasters (Adger et al. 2005b, Cutter et al. 2008, Taylor 2011, Henly-Shepard et al. 2015). Several important points emerge from this literature and the broader literature and case studies on adaptive capacity. First, both the local and broader contexts of change matter. Adaptive capacity may vary depending on the changes occurring, the linkages between local contexts and global processes, the ways that linkages manifest as effects on systems and individuals, local perceptions of desirable and undesirable system states and outcomes, and the characteristics of the system that determine the suite of available responses. In other words, it is crucial to define the adaptive capacity "of what," "to what," and "for whom" (Carpenter et al. 2001, Adger and Vincent 2005, Lebel et al. 2006, Adger et al. 2012).

Second, spatial and temporal scales of social and ecological change matter. SESs produce a suite of interacting ecosystem services at multiple scales, which support interdependent social systems. These complex systems are affected by cross-scale interactions whereby large-scale decisions affect small-scale systems, and small-scale adaptive characteristics add up to regionwide norms (Klein et al. 2014). Changes, effects, and responses are all critical factors for assessing adaptive capacity and occur and interact at multiple scales. Thus, the scale of assessment ("of what") is dependent on the scale of the given stressor ("to what;" Adger 2003, Adger and Vincent 2005, Folke et al. 2005, Biggs et al. 2012). Adaptive capacity in SESs can therefore be measured across scales such as household or population, cross-community or ecosystem, national, or regional levels. In an era of rapid transformative change, it is important that both social and ecological indicators be both robust and transparent and applicable to the scale of assessment to have meaningful policy applications (Adger and Vincent 2005).

Third, increasing interest in the concept of adaptive capacity has led to the development of numerous definitions as well as conceptual and analytical frameworks with associated measures and indicators. Many of these definitions and frameworks have primarily addressed either social or ecological adaptive capacity without integrating them. There is a need for integrated ways of thinking about adaptive capacity, with the caveat that not all SESs have tightly connected feedbacks. The direct feedback mechanism between changes in social or ecological systems may be missing or delayed in some contexts (buffered by social structures or other scales of resource availability, governance, or institutions beyond the scope of study). Furthermore, adaptive capacity should be assessed both in terms of the ability to react and change in response to opportunities (positive change) as well as stressors or challenges (negative change). There is no absolute measure of adaptive capacity, only adaptive capacity relative to the specific context, scale of disturbance, and scale of analysis.

Moving forward, some important gaps in adaptive capacity application are evident. There is much to learn about which measures and indicators of social and ecological adaptive capacity are the most powerful predictors of adaptive responses. Unfortunately, there are few instances in which assessments of adaptive capacity are followed up with monitoring or postassessment evaluation of change in that system through time. Future efforts should be made to follow up on single assessments of adaptive capacity to observe and describe whether assessments were accurate and which factors in particular enabled effective responses to both slow and rapid change. In addition, more attention is needed to develop integrated social-ecological assessments. In policy-relevant time scales, fostering adaptive capacity is most applicable to social systems, although it is possible to evaluate historical change in ecological adaptive capacity over longer time scales. Thus, it is imperative that management be focused on preventing the erosion of ecological adaptive capacity (e.g., through overfishing) and building social adaptive capacity through positive proactive action (futures thinking; Tschakert and Dietrich 2010). A learning opportunity for building consistency in adaptive capacity assessment could come from the fields of environmental impact assessment, management effectiveness evaluation, and social impact studies, where metrics for monitoring, evaluation, and reporting have a more developed history. Finally, there are limited published examples of assessments that demonstrate the linking of results from assessments to building of adaptive capacity. If adaptive capacity is to be a useful concept for fostering real world change, it is imperative that researchers and decision makers work across 
disciplines to develop clear, consistent methods that can support action-oriented outcomes that resonate with communities.

Responses to this article can be read online at: http://www.ecologyandsociety.org/issues/responses. php/9325

\begin{abstract}
Acknowledgments:
We thank Sam Gilchrist for help with the figures, and three anonymous reviewers whose comments greatly improved the manuscript. This research was supported by the Social Science and Humanities Research Council through the Ocean Canada Partnership (Pacific Working Group). Additional support was provided to C.K.W. through an NSERC Canada Graduate Scholarship (475091) and a Pacific Institute for Climate Solutions (PICS) fellowship, and to N.J.B. through a Liber Ero Fellowship in Conservation Science, a Fulbright Visiting Scholar Award, and a Banting Postdoctoral Fellowship. J.B. was supported by the Australian Centre for International Agricultural Research project FIS/2012/074.
\end{abstract}

\section{LITERATURE CITED}

Adger, W. N. 2000. Social and ecological resilience: Are they related? Progress in Human Geography 24(3):347-364. https://doi. org/10.1191/030913200701540465

Adger, W. N. 2003. Social capital, collective action, and adaptation to climate change. Economic Geography 79 (4):387-404. http://dx.doi.org/10.1111/j.1944-8287.2003.tb00220. $\underline{\mathrm{x}}$

Adger, W. N., S. Agrawala, M. M. Q. Mirza, C. Conde, K. O’Brien, J. Pulhin, R. Pulwarty, B. Smit, and K. Takahashi. 2007. Assessment of adaptation practices, options, constraints and capacity. Pages 717-743 in M. L. Parry, O. F. Canziani, J. P. Palutikof, P. J. van der Linden, and C. E. Hanson, editors. Climate change 2007: Working Group III: Contribution of Working Group II to the Fourth Assessment Report of the Intergovernmental Panel on Climate Change. Cambridge University Press, Cambridge, UK. [online] URL: http://www.ipcc.ch/publications and data/ar4/ wg2/en/ch17.html

Adger, W. N., N. W. Arnell, and E. L. Tompkins. 2005a. Successful adaptation to climate change across scales. Global Environmental Change 15(2):77-86. https://doi.org/10.1016/j.gloenvcha.2004.12.005

Adger, W. N., J. Barnett, K. Brown, N. Marshall, and K. O’Brien. 2012. Cultural dimensions of climate change impacts and adaptation. Nature Climate Change 3(2):112-117. http://dx.doi. org/10.1038/nclimate1666

Adger, W. N., T. P. Hughes, C. Folke, S. R. Carpenter, and J. Rockström. 2005b. Social-ecological resilience to coastal disasters. Science 309(5737):1036-1039. http://dx.doi.org/10.1126/ science. 1112122

Adger, W. N., and K. Vincent. 2005. Uncertainty in adaptive capacity. Comptes Rendus Geoscience 337(4):399-410. http://dx. doi.org/10.1016/j.crte.2004.11.004
Aguilera, S. E., J. Cole, E. M. Finkbeiner, E. Le Cornu, N. C. Ban, M. H. Carr, J. E. Cinner, L. B. Crowder, S. Gelcich, C. C. Hicks, J. N. Kittinger, R. Martone, D. Malone, C. Pomeroy, R. M. Starr, S. Seram, R. Zuercher, and K. Broad. 2015. Managing small-scale commercial fisheries for adaptive capacity: insights from dynamic social-ecological drivers of change in Monterey Bay. Plos One 10 (3):e0118992. http://dx.doi.org/10.1371/journal.pone.0118992

Aitken, S. N., S. Yeaman, J. A. Holliday, T. Wang, and S. CurtisMcLane. 2008. Adaptation, migration or extirpation: climate change outcomes for tree populations. Evolutionary Applications 1(1):95-111. http://dx.doi.org/10.1111/j.1752-4571.2007.00013.x

Allison, E. H., A. L. Perry, M.-C. Badjeck, W. N. Adger, K. Brown, D. Conway, A. S. Halls, G. M. Pilling, J. D. Reynolds, N. L. Andrew, and N. K. Dulvy. 2009. Vulnerability of national economies to the impacts of climate change on fisheries. Fish and Fisheries 10(2):173-196. http://dx.doi.org/10.1111/j.1467-2979.2008.00310. $\underline{\mathrm{X}}$

Armitage, D. 2005. Adaptive capacity and community-based natural resource management. Environmental Management 35 (6):703-715. http://dx.doi.org/10.1007/s00267-004-0076-Z

Armitage, D. R., and R. Plummer, editors. 2010. Adaptive capacity and environmental governance. Springer, Berlin, Germany. http:// dx.doi.org/10.1007/978-3-642-12194-4

Ban, N. C., M. Mills, J. Tam, C. C. Hicks, S. Klain, N. Stoeckl, M. C. Bottrill, J. Levine, R. L. Pressey, T. Satterfield, and K. M. Chan. 2013. A social-ecological approach to conservation planning: embedding social considerations. Frontiers in Ecology and the Environment 11(4):194-202. http://dx.doi.org/10.1890/110205

Basurto, X., S. Gelcich, and E. Ostrom. 2013. The socialecological system framework as a knowledge classification system for benthic small-scale fisheries. Global Environmental Change 23 (6):1366-1380. http://dx.doi.org/10.1016/j.gloenvcha.2013.08.001

Bennett, N. J. 2016. Using perceptions as evidence to improve conservation and environmental management. Conservation Biology 30(3):582-592. http://dx.doi.org/10.1111/cobi.12681

Bennett, N. J., J. Blythe, S. Tyler, and N. C. Ban. $2016 a$. Communities and change in the anthropocene: understanding social-ecological vulnerability and planning adaptations to multiple interacting exposures. Regional Environmental Change 16(4):907-926. http://dx.doi.org/10.1007/s10113-015-0839-5

Bennett, N. J., P. Dearden, G. Murray, and A. Kadfak. 2014. The capacity to adapt?: Communities in a changing climate, environment, and economy on the northern Andaman coast of Thailand. Ecology and Society 19(2):5. http://dx.doi.org/10.5751/ ES-06315-190205

Bennett, N. J., P. Dearden, and A. M. Peredo. 2015. Vulnerability to multiple stressors in coastal communities: a study of the Andaman coast of Thailand. Climate and Development 7 (2):124-141. http://dx.doi.org/10.1080/17565529.2014.886993

Bennett, N. J., A. Kadfak, and P. Dearden. 2016b. Communitybased scenario planning: a process for vulnerability analysis and adaptation planning to social-ecological change in coastal communities. Environment, Development and Sustainability 18 (6):1771-1799. http://dx.doi.org/10.1007/s10668-015-9707-1 
Benscoter, A. M., J. S. Reece, R. F. Noss, L. A. Brandt, F. J. Mazzotti, S. S. Romañach, and J. I. Watling. 2013. Threatened and endangered subspecies with vulnerable ecological traits also have high susceptibility to sea level rise and habitat fragmentation. Plos One 8(8):e70647. http://dx.doi.org/10.1371/journal.pone.0070647

Berkes, F., and D. Jolly. 2001. Adapting to climate change: socialecological resilience in a Canadian western Arctic community. Conservation Ecology 5(2):18. http://dx.doi.org/10.5751/es-00342-050218

Berman, R., C. Quinn, and J. Paavola. 2012. The role of institutions in the transformation of coping capacity to sustainable adaptive capacity. Environmental Development 2:86-100. http://dx.doi.org/10.1016/j.envdev.2012.03.017

Biggs, R., M. Schlüter, D. Biggs, E. L. Bohensky, S. BurnSilver, G. Cundill, V. Dakos, T. M. Daw, L. S. Evans, K. Kotschy, A. M. Leitch, C. Meek, A. Quinlan, C. Raudsepp-Hearne, M. D. Robards, M. L. Schoon, L. Schultz, and P. C. West. 2012. Toward principles for enhancing the resilience of ecosystem services. Annual Review of Environment and Resources 37:421-448. http:// dx.doi.org/10.1146/annurev-environ-051211-123836

Blythe, J. L., G. Murray, and M. Flaherty. 2014. Strengthening threatened communities through adaptation: insights from coastal Mozambique. Ecology and Society 19(2):6. http://dx.doi. org/10.5751/es-06408-190206

Bronen, R., and F. S. Chapin III. 2013. Adaptive governance and institutional strategies for climate-induced community relocations in Alaska. Proceedings of the National Academy of Sciences 110 (23):9320-9325. http://dx.doi.org/10.1073/pnas.1210508110

Brooks, N., W. N. Adger, and P. M. Kelly. 2005. The determinants of vulnerability and adaptive capacity at the national level and the implications for adaptation. Global Environmental Change 15 (2):151-163. http://dx.doi.org/10.1016/j.gloenvcha.2004.12.006

Bunce, M., S. Rosendo, and K. Brown. 2010. Perceptions of climate change, multiple stressors and livelihoods on marginal African coasts. Environment, Development and Sustainability 12 (3):407-440. http://dx.doi.org/10.1007/s10668-009-9203-6

Bundy, A., R. Chuenpagdee, S. R. Cooley, O. Defeo, B. Glaeser, P. Guillotreau, M. Isaacs, M. Mitsutaku, and R. I. Perry. 2015. A decision support tool for response to global change in marine systems: the IMBER-ADApT framework. Fish and Fisheries 17 (4):1183-1193. http://dx.doi.org/10.1111/faf.12110

Carpenter, S. R., and W. A. Brock. 2008. Adaptive capacity and traps. Ecology and Society 13(2):40. http://dx.doi.org/10.5751/ es-02716-130240

Carpenter, S., B. Walker, J. M. Anderies, and N. Abel. 2001. From metaphor to measurement: resilience of what to what? Ecosystems 4(8):765-781. http://dx.doi.org/10.1007/s10021-001-0045-9

Cheung, W. W. L., R. D. Brodeur, T. A. Okey, and D. Pauly. 2015. Projecting future changes in distributions of pelagic fish species of Northeast Pacific shelf seas. Progress in Oceanography 130:19-31. http://dx.doi.org/10.1016/j.pocean.2014.09.003

Cheung, W. W. L., V. W. Y. Lam, J. L. Sarmiento, K. Kearney, R. Watson, and D. Pauly. 2009. Projecting global marine biodiversity impacts under climate change scenarios. Fish and Fisheries 10 (3):235-251. http://dx.doi.org/10.1111/j.1467-2979.2008.00315.x
Cheung, W. W. L., V. W. Y. Lam, J. L. Sarmiento, K. Kearney, R. Watson, D. Zeller, and D. Pauly. 2010. Large-scale redistribution of maximum fisheries catch potential in the global ocean under climate change. Global Change Biology 16(1):24-35. http://dx.doi. org/10.1111/j.1365-2486.2009.01995.X

Chown, S. L., A. A. Hoffmann, T. N. Kristensen, M. J. Angilletta Jr., N. C. Stenseth, and C. Pertoldi. 2010. Adapting to climate change: a perspective from evolutionary physiology. Climate Research 43(1-2):3-15. http://dx.doi.org/10.3354/cr00879

Cinner, J. E. 2011. Social-ecological traps in reef fisheries. Global Environmental Change 21(3):835-839. http://dx.doi.org/10.1016/ j.gloenvcha.2011.04.012

Cinner, J. E., C. Huchery, E. S. Darling, A. T. Humphries, N. A. J. Graham, C. C. Hicks, N. Marshall, and T. R. McClanahan. 2013. Evaluating social and ecological vulnerability of coral reef fisheries to climate change. Plos One 8(9):e74321. http://dx.doi. org/10.1371/journal.pone.0074321

Cinner, J. E., C. Huchery, C. C. Hicks, T. M. Daw, N. Marshall, A. Wamukota, and E. H. Allison. 2015. Changes in adaptive capacity of Kenyan fishing communities. Nature Climate Change 5:872-876. http://dx.doi.org/10.1038/nclimate2690

Cinner, J. E., T. R. McClanahan, N. A. J. Graham, T. M. Daw, J. Maina, S. M. Stead, A. Wamukota, K. Brown, and Ö. Bodin. 2012. Vulnerability of coastal communities to key impacts of climate change on coral reef fisheries. Global Environmental Change 22(1):12-20. http://dx.doi.org/10.1016/j.gloenvcha.2011.09.018

Cote, M., and A. J. Nightingale. 2012. Resilience thinking meets social theory: situating social change in socio-ecological systems (SES) research. Progress in Human Geography 36(4):475-489. https://doi.org/10.1177/0309132511425708

Coulthard, S. 2012. Can we be both resilient and well, and what choices do people have? Incorporating agency into the resilience debate from a fisheries perspective. Ecology and Society 17(1):4. http://dx.doi.org/10.5751/ES-04483-170104

Crozier, L. G., and R. W. Zabel. 2006. Climate impacts at multiple scales: evidence for differential population responses in juvenile Chinook salmon. Journal of Animal Ecology 75(5):1100-1109. http://dx.doi.org/10.1111/j.1365-2656.2006.01130.x

Cutter, S. L., L. Barnes, M. Berry, C. Burton, E. Evans, E. Tate, and J. Webb. 2008. A place-based model for understanding community resilience to natural disasters. Global Environmental Change 18(4):598-606. http://dx.doi.org/10.1016/j.gloenvcha.2008.07.013

Daw, T. M., S. Coulthard, W. W. L. Cheung, K. Brown, C. Abunge, D. Galafassi, G. D. Peterson, T. R. McClanahan, J. O. Omukoto, and L. Munyi. 2015. Evaluating taboo trade-offs in ecosystems services and human well-being. Proceedings of the National Academy of Sciences 112(22):6949-6954. http://dx.doi.org/10.1073/ pnas. 1414900112

Dietz, T., E. Ostrom, and P. C. Stern. 2003. The struggle to govern the commons. Science 302(5652):1907-1912. http://dx.doi. org/10.1126/science.1091015

Dobzhansky, T. 1968. On some fundamental concepts of Darwinian biology. Pages 1-34 in T. Dobzhansky, M. K. Hecht, and W. C. Steere, editors. Evolutionary biology. Volume 2. 
Springer, New York, New York, USA. http://dx.doi. org/10.1007/978-1-4684-8094-8_1

Ekstrom, J. A., L. Suatoni, S. R. Cooley, L. H. Pendleton, G. G. Waldbusser, J. E. Cinner, J. Ritter, C. Langdon, R. van Hooidonk, D. Gledhill, K. Wellman, M. W. Beck, L. M. Brander, D. Rittschof, C. Doherty, P. E. T. Edwards, and R. Portela. 2015. Vulnerability and adaptation of US shellfisheries to ocean acidification. Nature Climate Change 5(3):207-214. http://dx.doi. org/10.1038/nclimate2508

Eliason, E. J., T. D. Clark, M. J. Hague, L. M. Hanson, Z. S. Gallagher, K. M. Jeffries, M. K. Gale, D. A. Patterson, S. G. Hinch, and A. P. Farrell. 2011. Differences in thermal tolerance among sockeye salmon populations. Science 332(6025):109-112. http://dx.doi.org/10.1126/science.1199158

Engle, N. L. 2011. Adaptive capacity and its assessment. Global Environmental Change 21(2):647-656. http://dx.doi.org/10.1016/ j.gloenvcha.2011.01.019

Fabinyi, M., L. Evans, and S. J. Foale. 2014. Social-ecological systems, social diversity, and power: insights from anthropology and political ecology. Ecology and Society 19(4):28. http://dx.doi. org/10.5751/es-07029-190428

Finkbeiner, E. M. 2015. The role of diversification in dynamic small-scale fisheries: lessons from Baja California Sur, Mexico. Global Environmental Change 32:139-152. http://dx.doi. org/10.1016/j.gloenvcha.2015.03.009

Folke, C., S. Carpenter, T. Elmqvist, L. Gunderson, C. S. Holling, and B. Walker. 2002. Resilience and sustainable development: building adaptive capacity in a world of transformations. Ambio 31(5):437-440. http://dx.doi.org/10.1579/0044-7447-31.5.437

Folke, C., T. Hahn, P. Olsson, and J. Norberg. 2005. Adaptive governance of social-ecological systems. Annual Review of Environment and Resources 30:441-473. http://dx.doi.org/10.1146/ annurev.energy.30.050504.144511

Gallopín, G. C. 2006. Linkages between vulnerability, resilience, and adaptive capacity. Global Environmental Change 16 (3):293-303. http://dx.doi.org/10.1016/j.gloenvcha.2006.02.004

Gattuso, J.-P., A. Magnan, R. Billé, W. W. L. Cheung, E. L. Howes, F. Joos, D. Allemand, L. Bopp, S. R. Cooley, C. M. Eakin, O. Hoegh-Guldberg, R. P. Kelly, H.-O. Pörtner, A. D. Rogers, J. M. Baxter, D. Laffoley, D. Osborn, A. Rankovic, J. Rochette, U. R. Sumaila, S. Treyer, and C. Turley. 2015. Contrasting futures for ocean and society from different anthropogenic $\mathrm{CO}_{2}$ emissions scenarios. Science 349(6243):aac4722. http://dx.doi.org/10.1126/ $\underline{\text { science.aac4722 }}$

Gidley, J. M., J. Fien, J.-A. Smith, D. C. Thomsen, and T. F. Smith. 2009. Participatory future methods: towards adaptability and resilience in climate-vulnerable communities. Environmental Policy and Goernance 19(6):427-440. http://dx.doi.org/10.1002/ eet. 524

Glandon, D. M. 2015. Measuring resilience is not enough; we must apply the research. Researchers and practitioners need a common language to make this happen. Ecology and Society 20 (2):27. http://dx.doi.org/10.5751/ES-07576-200227

Gupta, J., C. Termeer, J. Klostermann, S. Meijerink, M. van den Brink, P. Jong, S. Nooteboom, and E. Bergsma. 2010. The adaptive capacity wheel: a method to assess the inherent characteristics of institutions to enable the adaptive capacity of society. Environmental Science and Policy 13(6):459-471. http:// dx.doi.org/10.1016/j.envsci.2010.05.006

Hallegatte, S., C. Green, R. J. Nicholls, and J. Corfee-Morlot. 2013. Future flood losses in major coastal cities. Nature Climate Change 3(9):802-806. http://dx.doi.org/10.1038/nclimate1979

Harley, C. D. G., A. R. Hughes, K. M. Hultgren, B. G. Miner, C. J. B. Sorte, C. S. Thornber, L. F. Rodriguez, L. Tomanek, and S. L. Williams. 2006. The impacts of climate change in coastal marine systems. Ecology Letters 9(2):228-241. http://dx.doi. org/10.1111/j.1461-0248.2005.00871.x

Henly-Shepard, S., S. A. Gray, and L. J. Cox. 2015. The use of participatory modeling to promote social learning and facilitate community disaster planning. Environmental Science and Policy 45:109-122. http://dx.doi.org/10.1016/j.envsci.2014.10.004

Hicks, C. C., A. Levine, A. Agrawal, X. Basurto, S. J. Breslow, C. Carothers, S. Charnley, S. Coulthard, N. Dolsak, J. Donatuto, C. Garcia-Quijano, M. B. Mascia, K. Norman, M. R. Poe, T. Satterfield, K. St. Martin, and P. S. Levin. 2016. Engage key social concepts for sustainability. Science 352(6281):38-40. http://dx. doi.org/10.1126/science.aad4977

Hill, M., and N. L. Engle. 2013. Adaptive capacity: tensions across scales. Environmental Policy and Governance 23(3):177-192. http:// dx.doi.org/10.1002/eet.1610

Himes-Cornell, A., and S. Kasperski. 2015. Assessing climate change vulnerability in Alaska's fishing communities. Fisheries Research 162:1-11. http://dx.doi.org/10.1016/j.fishres.2014.09.010

Hinkel, J. 2011. "Indicators of vulnerability and adaptive capacity": towards a clarification of the science-policy interface. Global Environmental Change 21(1):198-208. http://dx.doi. org/10.1016/j.gloenvcha.2010.08.002

Holling, C. S. 1973. Resilience and stability of ecological systems. Annual Review of Ecology and Systematics 4:1-23. http://dx.doi. org/10.1146/annurev.es.04.110173.000245

Hutchings, J. A. 2011. Old wine in new bottles: reaction norms in salmonid fishes. Heredity 106(3):421-437. http://dx.doi. org/10.1038/hdy.2010.166

Intergovernmental Panel on Climate Change (IPCC). 2014. Annex II: glossary [K. J. Mach, S. Planton and C. von Stechow, editors]. Pages 117-130 in Climate change 2014: synthesis report. Contribution of Working Groups I, II and III to the Fifth Assessment Report of the Intergovernmental Panel on Climate Change [core writing team, R. K. Pachauri and L. A. Meyer, editors]. IPPC, Geneva, Switzerland. [online] URL: https://www. ipcc.ch/pdf/assessment-report/ar5/syr/AR5 SYR FINAL Annexes. pdf

Jensen, L. F., M. M. Hansen, C. Pertoldi, G. Holdensgaard, K.L. D. Mensberg, and V. Loeschcke. 2008. Local adaptation in brown trout early life-history traits: implications for climate change adaptability. Proceedings of the Royal Society $B$ 275:2859-2868. http://dx.doi.org/10.1098/rspb.2008.0870

Joakim, E. P., L. Mortsch, and G. Oulahen. 2015. Using vulnerability and resilience concepts to advance climate change adaptation. Environmental Hazards 14(2):137-155. http://dx.doi. org/10.1080/17477891.2014.1003777 
Johnson, C. R., S. C. Banks, N. S. Barrett, F. Cazassus, P. K. Dunstan, G. J. Edgar, S. D. Frusher, C. Gardner, M. Haddon, F. Helidoniotis, K. L. Hill, N. J. Holbrook, G. W. Hosie, P. R. Last, S. D. Ling, J. Melbourne-Thomas, K. Miller, G. T. Pecl, A. J. Richardson, K. R. Ridgway, S. R. Rintoul, D. A. Ritz, D. J. Ross, J. C. Sanderson, S. A. Shepherd, A. Slotwinski, K. M. Swadling, and N. Taw. 2011. Climate change cascades: shifts in oceanography, species' ranges and subtidal marine community dynamics in eastern Tasmania. Journal of Experimental Marine Biology and Ecology 400(1-2):17-32. http://dx.doi.org/10.1016/j. jembe.2011.02.032

Kalikoski, D. C., P. Quevedo Neto, and T. Almudi. 2010. Building adaptive capacity to climate variability: the case of artisanal fisheries in the estuary of the Patos Lagoon, Brazil. Marine Policy 34(4):742-751. http://dx.doi.org/10.1016/j.marpol.2010.02.003

Kareiva, P., and M. Marvier. 2012. What is conservation science? BioScience 62(11):962-969. http://dx.doi.org/10.1525/bio.2012.62.11.5

Kates, R. W., W. C. Clark, R. Corell, J. M. Hall, C. C. Jaeger, I. Lowe, J. J. McCarthy, H. J. Schellnhuber, B. Bolin, N M. Dickson, S. Faucheux, G. C. Gallopín, A. Grübler, B. Huntley, J. Jäger, N. S. Jodha, R. E. Kasperson, A. Mabogunje, P. Matson, H. Mooney, B. Moore III, T. O'Riordan, and U. Svedin. 2001. Sustainability science. Science 292(5517):641-642. http://dx.doi.org/10.1126/ science. 1059386

Kimmerer, R. W. 2013. Braiding sweetgrass: indigenous wisdom, scientific knowledge, and the teaching of plants. Milkweed Editions, Minneapolis, Minnesota, USA.

Klein, R. J. T., G. F. Midgley, B. L. Preston, M. Alam, F. G. H. Berkhout, K. Dow, and M. R. Shaw. 2014. Adaptation opportunities, constraints, and limits. Pages 899-943 in C. B. Field, V. R. Barros, D. J. Dokken, K. J. Mach, M. D. Mastrandrea, T. E. Bilir, M. Chatterjee, K. L. Ebi, Y. O. Estrada, R. C. Genova, B. Girma, E. S. Kissel, A. N. Levy, S. MacCracken, P. R. Mastrandrea, and L. L. White, editors. Climate change 2014: impacts, adaptation, and vulnerability. Part A: global and sectoral aspects. Contribution of Working Group II to the Fifth Assessment Report of the Intergovernmental Panel on Climate Change. Cambridge University Press, Cambridge, UK. [online] URL: http://www.ipcc.ch/pdf/assessment-report/ar5/wg2/WGIIAR5Chap16 FINAL.pdf

Kueffer, C., and C. N. Kaiser-Bunbury. 2014. Reconciling conflicting perspectives for biodiversity conservation in the Anthropocene. Frontiers in Ecology and the Environment 12 (2):131-137. http://dx.doi.org/10.1890/120201

Lebel, L., J. M. Anderies, B. Campbell, C. Folke, S. HatfieldDodds, T. P. Hughes, and J. Wilson. 2006. Governance and the capacity to manage resilience in regional social-ecological systems. Ecology and Society 11(1):19. http://dx.doi.org/10.5751/ es-01606-110119

Malakar, Y. 2013. Increasing adaptive capacity: What is the role of local institutions? Risk, Hazards, and Crisis in Public Policy 3 (4):60-76. http://dx.doi.org/10.1002/rhc3.18

Marshall, N. A., P. A. Marshall, J. Tamelander, D. Obura, D. Malleret-King, and J. E. Cinner. 2010. A framework for social adaptation to climate change: sustaining tropical coastal communitites and industries. IUCN, Gland, Switzerland. [online] URL: https://portals.iucn.org/library/efiles/documents/2010-022. pdf

Marshall, N. A., S. Park, S. M. Howden, A. B. Dowd, and E. S. Jakku. 2013. Climate change awareness is associated with enhanced adaptive capacity. Agricultural Systems 117:30-34. http://dx.doi.org/10.1016/j.agsy.2013.01.003

Mawdsley, J. R., R. O’Malley, and D. S. Ojima. 2009. A review of climate-change adaptation strategies for wildlife management and biodiversity conservation. Conservation Biology 23 (5):1080-1089. http://dx.doi.org/10.1111/j.1523-1739.2009.01264. $\underline{\mathrm{x}}$

McClanahan, T. R., J. E. Cinner, J. Maina, N. A. J. Graham, T. M. Daw, S. M. Stead, A. Wamukota, K. Brown, M. Ateweberhan, V. Venus, and N. V. C. Polunin. 2008. Conservation action in a changing climate. Conservation Letters 1(2):53-59. http://dx.doi. org/10.1111/j.1755-263X.2008.00008 1.X

McGinnis, M. D., and E. Ostrom. 2014. Social-ecological system framework: initial changes and continuing challenges. Ecology and Society 19(2):30. http://dx.doi.org/10.5751/es-06387-190230

Mcleod, E., B. Szuster, J. Hinkel, E. L. Tompkins, N. Marshall, T. Downing, S. Wongbusarakum, A. Patwardhan, M. Hamza, C. Anderson, S. Bharwani, L. Hansen, and P. Rubinoff. 2016. Conservation organizations need to consider adaptive capacity: why local input matters. Conservation Letters 9(5):351-360. http:// dx.doi.org/10.1111/conl.12210

Mills, M., R. Weeks, R. L. Pressey, M. G. Gleason, R.-L. EismaOsorio, A. T. Lombard, J. M. Harris, A. B. Killmer, A. White, and T. H. Morrison. 2015. Real-world progress in overcoming the challenges of adaptive spatial planning in marine protected areas. Biological Conservation 181:54-63. http://dx.doi.org/10.1016/j. biocon.2014.10.028

Moore, A. 2016. Anthropocene anthropology: reconceptualizing contemporary global change. Journal of the Royal Anthropological Institute 22(1):27-46. http://dx.doi. org/10.1111/1467-9655.12332

Nemec, K. T., J. Chan, C. Hoffman, T. L. Spanbauer, J. A. Hamm, C. R. Allen, T. Hefley, D. Pan, and P. Shrestha. 2013. Assessing resilience in stressed watersheds. Ecology and Society 19(1):34. http://dx.doi.org/10.5751/es-06156-190134

O'Connor, M. I., E. R. Selig, M. L. Pinsky, and F. Altermatt. 2012. Toward a conceptual synthesis for climate change responses. Global Ecology and Biogeography 21(7):693-703. http://dx.doi. org/10.1111/j.1466-8238.2011.00713.X

Oteros-Rozas, E., B. Martín-López, T. M. Daw, E. L. Bohensky, J. R. A. Butler, R. Hill, J. Martin-Ortega, A. Quinlan, F. Ravera, I. Ruiz-Mallén, M. Thyresson, J. Mistry, I. Palomo, G. D. Peterson, T. Plieninger, K. A. Waylen, D. M. Beach, I. C. Bohnet, M. Hamann, J. Hanspach, K. Hubacek, S. Lavorel, and S. P. Vilardy. 2015. Participatory scenario planning in place-based social-ecological research: insights and experiences from 23 case studies. Ecology and Society 20(4):32. http://dx.doi.org/10.5751/ ES-07985-200432 
Pelling, M., and C. High. 2005. Understanding adaptation: What can social capital offer assessments of adaptive capacity? Global Environmental Change 15(4):308-319. https://doi.org/10.1016/j. gloenvcha.2005.02.001

Perry, R. I., M. Barange, and R. E. Ommer. 2010. Global changes in marine systems: a social-ecological approach. Progress in Oceanography 87(1-4):331-337. http://dx.doi.org/10.1016/j. pocean.2010.09.010

Peterson, G. D., G. S. Cumming, and S. R. Carpenter. 2003. Scenario planning: a tool for conservation in an uncertain world. Conservation Biology 17(2):358-366. http://dx.doi.org/10.1046/ j.1523-1739.2003.01491.x

Pramova, E., B. Locatelli, H. Djoudi, and O. A. Somorin. 2012. Forests and trees for social adaptation to climate variability and change. Wiley Interdisciplinary Reviews: Climate Change 3 (6):581-596. http://dx.doi.org/10.1002/wcc.195

Salafsky, N., D. Salzer, A. J. Stattersfield, C. Hilton-Taylor, R. Neurgarten, S. H. M. Butchart, B. Collen, N. Cox, L. L. Master, S. O'Connor, and D. Wilkie. 2008. A standard lexicon for biodiversity conservation: unified classifications of threats and actions. Conservation Biology 22(4):897-911. http://dx.doi. org/10.1111/j.1523-1739.2008.00937.X

Sales, R. F. M. Jr. 2009. Vulnerability and adaptation of coastal communities to climate variability and sea-level rise: their implications for integrated coastal management in Cavite City, Philippines. Ocean and Coastal Management 52(7):395-404. http://dx.doi.org/10.1016/j.ocecoaman.2009.04.007

Senos, R., F. K. Lake, N. J. Turner, and D. Martinez. 2006. Traditional ecological knowledge and restoration practice. Pages 393-426 in D. Apostol and M. Sinclair, editors. Restoring the Pacific Northwest: the art and science of ecological restoration in Cascadia. Island Press, Washington, D.C., USA. [online] URL: https://www.treesearch.fs.fed.us/pubs/50696

Smit, B., and J. Wandel. 2006. Adaptation, adaptive capacity and vulnerability. Global Environmental Change 16(3):282-292. http:// dx.doi.org/10.1016/j.gloenvcha.2006.03.008

Steffen, W., Å. Persson, L. Deutsch, J. Zalasiewicz, M. Williams, K. Richardson, C. Crumley, P. Crutzen, C. Folke, L. Gordon, M. Molina, V. Ramanathan, J. Rockström, M. Scheffer, H. J. Schellnhuber, and U. Svedin. 2011. The anthropocene: from global change to planetary stewardship. Ambio 40(7):739-761. http://dx.doi.org/10.1007/s13280-011-0185-x

Stillman, J. H. 2003. Acclimation capacity underlies susceptibility to climate change. Science 301(5629):65. http://dx.doi. org/10.1126/science.1083073

Sunday, J. M., A. E. Bates, and N. K. Dulvy. 2011. Global analysis of thermal tolerance and latitude in ectotherms. Proceedings of the Royal Society B 278:1823-1830. http://dx.doi.org/10.1098/ rspb.2010.1295

Taylor, J. 2011. Community-based vulnerability assessment: Semarang, Indonesia. Pages 111-121 in Resilient cities: cities and adaptation to climate change: proceedings of the Global Forum 2010. Springer, Dordrecht, The Netherlands. http://dx.doi. org/10.1007/978-94-007-0785-6 34
Tol, R. S. J., M. Bohn, T. E. Downing, M.-L. Guillerminet, E. Hizsnyik, R. Kasperson, K. Lonsdale, C. Mays, R. J. Nicholls, A. A. Olsthoorn, G. Pfeifle, M. Poumadere, F. L. Toth, A. T. Vafeidis, P. E. van der Werff, and I. H. Yetkiner. 2006. Adaptation to five metres of sea level rise. Journal of Risk Research 9(5):467-482. http://dx.doi.org/10.1080/13669870600717632

Tompkins, E. L., R. Few, and K. Brown. 2008. Scenario-based stakeholder engagement: incorporating stakeholders preferences into coastal planning for climate change. Journal of Environmental Management 88(4):1580-1592. http://dx.doi.org/10.1016/j. jenvman.2007.07.025

Tschakert, P. 2007. Views from the vulnerable: understanding climatic and other stressors in the Sahel. Global Environmental Change 17(3-4):381-396. http://dx.doi.org/10.1016/j.

gloenvcha.2006.11.008

Tschakert, P., and K. A. Dietrich. 2010. Anticipatory learning for climate change adaptation and resilience. Ecology and Society 15 (2):11. http://dx.doi.org/10.5751/es-03335-150211

Tuler, S., J. Agyeman, P. Pinto da Silva, K. R. LoRusso, and R. Kay. 2008. Assessing vulnerabilities: integrating information about driving forces that affect risks and resilience in fishing communities. Human Ecology Review 15(2):171-184. [online] URL: http://ww.w.humanecologyreview.org/pastissues/her152/ tuleretal.pdf

Turner, N. J. 2014. Ancient pathways, ancestral knowledge: ethnobotany and ecological wisdom of indigenous peoples of northwestern North America. McGill-Queen's University Press, Montreal, Canada.

Turner, N. J., and H. Clifton. 2009. "It's so different today": climate change and indigenous lifeways in British Columbia, Canada. Global Environmental Change 19(2):180-190. http://dx. doi.org/10.1016/j.gloenvcha.2009.01.005

Walker, B. H., N. Abel, J. M. Anderies, and P. Ryan. 2009. Resilience, adaptability, and transformability in the GoulburnBroken catchment, Australia. Ecology and Society 14(1):12. http://dx.doi.org/10.5751/es-02824-140112

Walker, B., S. Carpenter, J. Anderies, N. Abel, G. Cumming, M. Janssen, L. Lebel, J. Norberg, G. D. Peterson, and R. Pritchard. 2002. Resilience management in social-ecological systems: a working hypothesis for a participatory approach. Conservation Ecology 6(1):14. [online] URL: http://www.consecol.org/vol6/ iss $1 / \operatorname{art14}$

Walker B., and D. Salt. 2006. Resilience thinking: sustaining ecosystems and people in a changing world. Island Press, Washington, D.C., USA.

Wang, J., X. Huang, T. Zhong, and Z. Chen. 2013. Climate change impacts and adaptation for saline agriculture in north Jiangsu Province, China. Environmental Science and Policy 25:83-93. http://dx.doi.org/10.1016/j.envsci.2012.07.011

Weatherdon, L. V., A. K. Magnan, A. D. Rogers, U. R. Sumaila, and W. W. L. Cheung. 2016a. Observed and projected impacts of climate change on marine fisheries, aquaculture, coastal tourism, and human health: an update. Frontiers in Marine Science 3:48. https://doi.org/10.3389/fmars.2016.00048 
Weatherdon, L. V., Y. Ota, M. C. Jones, D. A. Close, and W. W. L. Cheung. 2016b. Projected scenarios for coastal First Nations' fisheries catch potential under climate change: management challenges and opportunities. Plos One 11(1):e0145285. https:// doi.org/10.1371/journal.pone.0145285

Whitney, C. K., S. G. Hinch, and D. A. Patterson. 2013. Provenance matters: thermal reaction norms for embryo survival among sockeye salmon Oncorhynchus nerka populations. Journal of Fish Biology 82(4):1159-1176. http://dx.doi.org/10.1111/ jfb. 12055

Wiek, A., F. Farioli, K. Fukushi, and M. Yarime. 2012. Sustainability science: bridging the gap between science and society. Sustainability Science 7(S1):1-4. http://dx.doi.org/10.1007/ $\underline{\text { s11625-011-0154-0 }}$

Wong, P. P., I. J. Losada, J.-P. Gattuso, J. Hinkel, A. Khattabi, K. L. McInnes, Y. Saito, and A. Sallenger. 2014. Coastal systems and low-lying areas. Pages 361-409 in C. B. Field, V. R. Barros, D. J. Dokken, K. J. Mach, M. D. Mastrandrea, T. E. Bilir, M. Chatterjee, K. L. Ebi, Y. O. Estrada, R. C. Genova, B. Girma, E. S. Kessel, A. N. Levy, S. MacCracken, P. R. Mastrandrea, and L. L. White, editors. Climate change 2014: impacts, adaptation, and vulnerability. Part A: global and sectoral aspects. Contribution of Working Group II to the Fifth Assessment Report of the Intergovernmental Panel on Climate Change. Cambridge University Press, Cambridge, UK. [online] URL: http://www. ipcc.ch/pdf/assessment-report/ar5/wg2/WGIIAR5-Chap5 FINAL. pdf

Worm, B., E. B. Barbier, N. Beaumont, J. E. Duffy, C. Folke, B. S. Halpern, J. B. C. Jackson, H. K. Lotze, F. Micheli, S. R. Palumbi, E. Sala, K. A. Selkoe, J. J. Stachowicz, and R. Watson. 2006. Impacts of biodiversity loss on ocean ecosystem services. Science 314(5800):787-790. http://dx.doi.org/10.1126/science.1132294

Yohe, G., and R. S. J. Tol. 2002. Indicators for social and economic coping capacity-moving toward a working definition of adaptive capacity. Global Environment 12(1):25-40. http://dx.doi. org/10.1016/S0959-3780(01)00026-7 
Appendix \#1 Comparison of 11 Approaches for Analyzing Adaptive Capacity: Strengths, weaknesses, insights, implications and applications. Key references are included of case study examples and reviews for each method, where available.

\begin{tabular}{|c|c|c|c|c|c|}
\hline Approach & Description & Details & Strengths, Weaknesses & $\begin{array}{c}\text { Insights, Implications, } \\
\text { Application }\end{array}$ & $\begin{array}{c}\text { Key } \\
\text { References }\end{array}$ \\
\hline $\begin{array}{l}\text { Large scale } \\
\text { social } \\
\text { indicators }\end{array}$ & $\begin{array}{l}\text { Studies of relative adaptive } \\
\text { capacity (or inversely related } \\
\text { indicators of vulnerability), } \\
\text { based on existing socio- } \\
\text { economic or social data across } \\
\text { the system. }\end{array}$ & $\begin{array}{l}\text { Key Methods: Relative } \\
\text { community assessments of risk } \\
\text { exposure (e.g. to climate } \\
\text { change), system sensitivity } \\
\text { (i.e. resource dependence), and } \\
\text { adaptive capacity of the social } \\
\text { system (wealth, governance, } \\
\text { assets, learning, etc.). } \\
\text { System focus: Social } \\
\text { Scale of Analysis: } \\
\text { Communities to state to cross- } \\
\text { national } \\
\text { Temporal Focus: Present }\end{array}$ & $\begin{array}{l}\text { Strengths: Can provide rapid } \\
\text { outcomes for decision makers, } \\
\text { and be useful for communicating } \\
\text { differences in vulnerability and } \\
\text { adaptive capacity among different } \\
\text { regions, populations and } \\
\text { communities. Relatively easy to } \\
\text { conduct - relies on simple surveys } \\
\text { at community level (e.g. from } \\
\text { focus groups and RRA type } \\
\text { research) or on secondary data. } \\
\text { Weakness: Indices are often } \\
\text { generic, theoretical, and } \\
\text { composite: Difficult to evaluate. } \\
\text { Doesn't allow for evaluations of } \\
\text { the effectiveness of responses; } \\
\text { difficult to incorporate traditional } \\
\text { or cultural knowledge. Relative } \\
\text { measures only; difficult to apply } \\
\text { to policy for building adaptive } \\
\text { capacity in a particular place. }\end{array}$ & $\begin{array}{l}\text { Insights: Allows a broad } \\
\text { understanding of potential } \\
\text { relative response to stress or } \\
\text { opportunities, generally related } \\
\text { to how the combination of } \\
\text { hazard exposure, dependency } \\
\text { (sensitivity) and adaptive } \\
\text { capacity led to differential } \\
\text { vulnerability. } \\
\text { Implications \& Applications: } \\
\text { Local management is not very } \\
\text { responsive at this scale. } \\
\text { Useful for policy and } \\
\text { governance insights across } \\
\text { communities or regions. }\end{array}$ & $\begin{array}{l}\text { (Himes- } \\
\text { Cornell et al. } \\
\text { 2016) } \\
\text { (Himes- } \\
\text { Cornell and } \\
\text { Kasperski } \\
\text { 2015) } \\
\text { (Barange et } \\
\text { al. 2014) } \\
\text { (Hughes et al. } \\
\text { 2012) } \\
\text { (Allison et al. } \\
\text { 2009) } \\
\text { (Brooks et al. } \\
\text { 2005) } \\
\text { (Yohe and } \\
\text { Tol 2002) }\end{array}$ \\
\hline
\end{tabular}


Large scale ecological indicators and models

Modeling of past and present ecological changes and future adaptation potential of species and fisheries along with projected environmental changes
Key Methods: Mean responses to changes in environmental conditions: species distribution shifts, species' adaptive capacity index, rate of evolutionary changes.

Attention to: Ecological

Scale of Analysis: Species,

biological communities, and

fisheries (e.g. Large Marine

Ecosystem scale)

Temporal Focus: Past, present and future.
Strengths: Reveal large-scale pattern of adaptive responses and capacity to adapt to ecological change from both the perspective of species, and the fishery response to that change.

Weakness: Low resolution because of limitation of data or model, need downscaling to be directly usable for regional and local scale studies; confidence is limited by the state of knowledge on species' and fisheries' adaptive responses.
Insights: Understand how

species are responding to

changing conditions through

distributional changes, and how

some fisheries are adapting to

that through changes in species

composition of catches.

Implications \& Applications:

The rate of evolutionary

adaptation may not be fast

enough under the current rate of

warming, particularly for species

that have a low adaptive

capacity (e.g., low genetic

variability, slow turn-over rate).

This tool is policy relevant for

larger regional/national

governance, and can be applied

to identify species/fisheries most

vulnerable to climate change.
(Cheung et

al. 2013)

(Cheung et

al. 2012)

(Gattuso et

al. 2015)

(Cheung et

al. 2015)

(Sumaila et

al. 2011)

(Lam et al.

2014) 
Integrated socialecological indicators

Studies of the adaptive capacity of social-ecological systems based on existing socio-economic and ecological data within or across systems
Governance approaches
Key Methods: Assesses the adaptive capacity of socialecological systems based on ecological and social data (e.g. time series of catches,

biomass, ocean conditions, market price, participation)

Uses existing data, key informant interviews. E.g. IMBER ADApT (Assessment of Responses based on Description, Appraisal and Typology): Vulnerability, Governability, Response and Appraisal.

Attention to: Social-ecological

Scale of Analysis: At all scales: Individual to multicommunities to state to crossnational

Temporal Focus: Past to present, with lessons for future integration of existing studies.
Approach to understand the role of institutions (rights, rules, norms) and governance dimensions of vulnerability and AC. Assessments not typically framed a priori by
Key Methods: Assessment of governance often through conventional social science techniques (semi-structured interviews, focus groups, etc.); properties and characteristics of the system into a smaller number of variables with similar or greater descriptive power (similar to indicators of human health)

\section{E.g. The I-ADApT framework} combines both quantitative and qualitative responses to enable more explanation of motivation, etc. The questionnaire format allows people involved in the event to express their opinions. Responses can be timely (e.g. as an event is happening) and does not necessarily rely on subsequent written/published reports.

Weakness: Data intensive. Often considers relative measures: difficult to apply to local management. No evaluations of effectiveness of responses. Can be at an overly coarse scale with less application to local communities.
Strengths: Combines multiple

Strengths: Opportunity to consider the role of existing institutions and governance arrangements in facilitating capacity of communities to adapt to change (i.e., as a dimensions of
Insights: Understanding of trade offs in fisheries adaptation: In times of rapid change (i.e.

climate change), allowing for adaptability by fishers will be critical for the survival of their livelihoods.

The I-ADApT framework provides insights which include both natural and social system attributes and responses, as well as how they were integrated. Practical solutions pertain to how scientists, managers, and communities involved in the event responded, at both short and longer time and spatial scales, across cases.

Implications \& Applications: Need more rapid and effective responses to marine socialecological crises/events relevant at a larger

policy/governance level for management. IMBER-ADApT can be applied across cases based on a core set of indicators. This method has been applied to case studies (e.g., Monterey Bay, California), and is currently in development.

(Aguilera et

al. 2015)

(Bundy et al. 2015)

(Perry et al 2011)

(Barange et al. 2010)

(Miller et al.

(Cinner et al. 2013)

(Cinner et al.

Insights: Understand the role of networks and multilevel governance important attribute of adaptive capacity

tz et al. 2003)

(Gupta et al. 2010)

Institutions as pathways for 
suites of indicators, but rather insights on institutional and governance dimensions of vulnerability and AC developed inductively from case experiences. Where the focus has been more directly oriented towards institutions/governance, some established attributes and indicators are available. sometimes indicators used

Attention to: Linked socialecological systems and role of institutions and governance processes in mediating human interaction with the environment

Scale of Analysis: Local (community-based institutions and governance arrangements) to macro (national, supranational arrangements)

Temporal Focus: Past, Present; Possible to use for future scenario planning.

Key Methods: Household surveys, semi-structured interviews, focus groups

Studies between several surveys communities where adaptive capacity is measured through assets and actions taken to respond to change. Indicators based on the 5 capitals (human, financial, physical, social, natural) and adaptive strategies. vulnerable and adaptive capacity); the importance of assessing the capacity of actors to modify institutions in response to change; and that governance is multi-

faceted and requires assessments of daily practices of governance, issues of institutional design and its implications, and values and principles that frame governance

Weakness: Limited attention to relations of power; emphasis is on governance as context, rather than an analytical lens with which to consider principles and values, institutional design, social practices (e.g. learning).

Inadequate attention to the nature of change (i.e. incremental change versus thresholds of change or regime shifts)

Attention to: Interactions between social and ecological stressors, livelihoods

Scale of Analysis: Household to community

Temporal Focus: Recent past (1 year) to present

Strengths: Allows for inclusion of cultural, historical, or traditional adaptive techniques.

Leads to an understanding of potential barriers to adaptation

Personal descriptions of adaptations show that strategies vary by socio-economic status (e.g. diversification vs. (e.g., economic, cultural).

intensification for poor to wealthy fishers), with differentially

impacts on the ecological system

Insights: Insights into how socia knowledge co-production and social learning needed for adaptive capacity

Understanding of communitybased institutions (customary practices, norms) as sources of adaptive capacity, renewal.

Implications \& Applications: Enhanced understanding of the social and institutional (formal, non-formal) capacity of actors at multiple levels to make decisions about adaptation, and the linkages/feedbacks among decision making levels about adaptive capacity.

Opportunity to apply governance and institutional assessments at multiple levels; contribute to bottom-up and top-down assessments of vulnerability and adaptive capacity.

2009)

(Brown et al.

(Smit and

Wandel

2006)

(Armitage and Plummer dynamics constrain or facilitate adaption and what the social/ecological consequences might be (e.g., intensification can increase pressure on resource), which provides better information for intervention depending on the goal of the intervention (e.g., interventions trying to reduce pressure on the esource by diversifying wealthy fishers' livelihoods may not work in this context).
Blythe 2014)

(Blythe et al. 2015)

(Blythe et al. 2014)

(Cinner et al. 2011) 
(e.g., diminishing vs. amplifying feedbacks).

Weakness: Lower explanatory power and intervention actions as specific strategies are highly context specific

\section{Social} experiments

Social: Field economic experiments where individuals make hypothetical decisions (for economic rewards) based on real-world daily decisions and behaviors relevant to their livelihoods and context.
Key Methods: Economic experiments: Individual choice behavior

\section{(Catch decisions).}

Attention to: Social

Scale of Analysis: Local (individual and community)

\section{Temporal Focus:}

Fishers are using past experiences to make catch decisions in the present (which is what we are measuring), and are also reflecting on how these lessons are applicable for the future.

\section{Key Methods:}

Species leve experiments which the responses of populations within a single species are assessed with respect to a particular stressor (e.g. temperature, water chemistry). The objective is to assess adaptive capacity
Ecological experiments assess genotypic or phenotypic variation in observable traits (or loci) within species or populations exposed to different environmental conditions (e.g. temperature
Strengths: Allows researcher to understand fisher decisions in response to different sources of uncertainty in a controlled and replicable way. May also have pedagogical value in providing a platform for reflection in an interactive environment about daily decisions and behavior.

Weakness: Unless used with other approaches (i.e. interviews, surveys) does not answer questions about why some fishers respond and behave differently or have different levels of adaptive capacity.

Strengths: Conceptually simple experimental design (e.g. factorial breeding designs); Provides quantitative estimates of genetic variation, heritability or phenotypic plasticity for species and/or populations of species; Can provide evolutionary potential
Implications \& Applications: A more nuanced understanding of livelihood diversification as an adaptation strategy and of material wealth as for a potential barrier for adaptation. Methods can inform interventions to foster adaptive capacity or reduce vulnerability in

communities or across sectors

Insights: Fishers (within this context) have agency to confront change and uncertainty by adjusting their fishing behaviors to counteract declines in fishery resources. It is a useful way to look at the social-ecological feedbacks of multiple drivers.

Implications \& Applications:

Using this method provides an interactive space for reflection which could induce favorable increased communication) or unfavorable (exacerbation of power asymmetries) changes in the community itself. No known applications of the results to action.

Insights: Provides speciesspecific quantitative assessment of evolutionary potential; quantitative estimates obtained can be combined with demographic information in model simulations to predict future species persistence and
(Camilo

Cardenas and

Carpenter 2005)

(Castillo et

al. 2011)

(Gelcich et al. 2013).

(Finkbeiner

(Bernhardt and Leslie 2011).

(Jensen et al. 2008)

(Reed et al. 
(genotypic variation and/or phenotypic plasticity) to variation in environmental conditions
Historical ethnographic approaches
Analysis of past adaptive responses within a community or among several communities; at a household or community level. Indicators are based on historical knowledge, traditional engagement with ecological community, traditional ecological knowledge (TEK) holders different $\mathrm{CO} 2$ concentrations). based on a single generation.

E.g. Breeding designs,

"common garden"

experiments, molecular or

genomics approaches, metaanalyses.

Attention to: Ecological

Scale of Analysis: Multiple populations/stocks (regional)

Temporal Focus: Assess genetic adaptation or plasticity in traits to help explain current species distributions or predict future adaptive and evolutionary species responses.

Key Methods: Understanding traditional knowledge systems and past adaptations;

identifying times of change or stress in

historical/archaeological record, oral histories, and personal experiences and analyzing responses to change

Attention to: Social-ecological (integration)

Scale of Analysis: Local to regional

Temporal Focus: Past, recent natural variability in aquatic systems. Does not account for $\mathrm{CO}_{2}$ ) or trait correlations; life-history stage or single generation do not capture multigenerational evolutionary potential. types and scale of change, and people can relate to changes contemporary circumstances

Weakness: Past changes an acceptance; Not necessarily applicable at large scales. community dynamics; gain on the number of species and/or populations that can be included in a single study; Controlled lab experiment does not account for multiple interacting stressors (e.g. increased temperature and higher Experiments that target specific

Strengths: Understanding of past what cultural/social/ ecological adaptations occurred in response; experienced by ancestral peoples; can inspire adaptive capacity in adaptations many not be relevant to modern circumstances; Takes time to gain community trust and

communities. Strong social insight into what species and/or populations have more/less potential for future adaptation.

2011)

(Crozier et al. 2008)

Implications \& Applications:

Susceptibility to changing environmental conditions varies between species and between populations of the same species: implications for species management (e.g. managing to maintain stock diversity or standing genetic variation, fisheries targeting, and species conservation priorities and approaches). Can apply to selection of

populations/stocks/species for aquaculture, hatchery breeding programs), changes to fisheries objectives.

Insights: Knowledge

(Alcorn et al. transmission and sharing through stories and ceremonies contributes greatly to adaptive capacity of people and

(Hutchings 2011)

(Whitney et

(Munday et al. 2013)

(Sunday et al. 2011)

(Muñoz et al.

structures really help

communities adapt, along with access to resources. Knowing how ancestors have responded to and overcome changes and

difficulties can inspire people to face and adapt to change in their own lives

(Berkes

(Berkes et al. 2000)

(Berkes et al. 2003)

(Ford and Martinez 2000)

Implications \& Applications: Communities where strong ties 
and distant

Participatory planning approaches
Urban and regional planning for resilience related to changing hydrological systems and risk assessments
Key Methods: Mixed methods: interviews, a regional survey and participant observation at key regional planning events over 3 years [and] participatory action research. Planning approaches to adaptive capacity have ranged from 'participatory futures approaches' to community-based climate change adaptation (by engaging and empowering community members to be active collaborators in revisioning and developing scenarios about their communities that facilitates co-evolutionary adaptation to climate change rather than passive adaptation.

Attention to: Socio-ecologica system
Strengths: Comprehensive multiple streams of evidence, easy to triangulate evidence types.

Participatory action research can foster new knowledge, learning, and action to support positive social/environmental change through reconfiguring the standard processes of knowledge production. An informal collaborative can be seen as a safe shadow space for learning more inclusive and less political that other regional forums where thinking out loud, revealing uncertainties, collectively troubleshooting and learning from neighbouring municipalities may not be doable or would be considered as inappropriate (less inclusive).

Weakness: Very time consuming along environmental and social between generations are apparent also benefit from adapting to change; access to traditional knowledge is important. Community leaders and others who are trained from a very young age provide knowledge bank to draw from. The use of stories, ceremony, art, to convey experiences of past adaptation can inspire and inform adaptation to changes today, and inform ecological restoration.

2006)

(Senos et al. 2006)

(Turner

2014)

Insights: Participatory

vulnerability assessments can help identify adaptation strategies that are most feasible and practical in communities with a focus on risks that are already problematic; while climate stresses are reviewed stresses, allowing for integration and co-benefits with resource management, disaster preparedness and sustainable development initiatives.

Implications \& Applications: Allows for in-depth understanding and building of adaptive capacity which can serve as an effective link from assessment to action. This methodology allows to identify and address specific hazards and risks while building a
(Pelling et al 2008)

(Folke et al.

(Gidley et al. 2009)

(Smit and

Wande 2006)

(Ballard and Belsky 2010)

(Tschakert and Dietrich 


$\begin{array}{ll}\text { Qualitative } & \text { Inductive qualitative } \\ \text { interview } & \text { assessment within a } \\ \text { approaches } & \text { community using local } \\ & \text { knowledge engagement. } \\ & \text { Indicators include various } \\ & \text { assets, organizations, and } \\ & \text { other supports that } \\ & \text { interviewees mentioned help } \\ & \text { or have helped them adapt to } \\ \text { changes and their impacts. }\end{array}$

Scale of Analysis: Community (municipal), sub-regional, and regional

Temporal Focus: Past (historical adaptations), present, and future

Key Methods: Interviews and focus groups; unstructured and semi-structured interview format

Attention to: Social and ecological components

Scale of Analysis:

Household to community

Temporal Focus: Past and present impacts of change and drivers of adaptive capacity
Strengths: Gives an in-depth understanding of a community with household or individual responses to change. Builds a relationship with that community. Based on self-perception of adaptive capacity from the perspective of the community members themselves.

Weakness: Very time intensive; requires community buy-in, often pre-existing relationships or understanding of the community are critical. Need to build trust to collect information. generalized capacity to address change. Study findings may inform local and metropolitan scale actions by partner organizations.

Insights: Gain a greater range of the elements of adaptive capacity. Appreciate the nuance of limitations and opportunities at an individual or household level. Insights included: 1) types and trajectories of significant processes of change being experienced by community members, 2) the array of responses being taken to change and 3 ) the mechanisms that either inhibit or strengthen ability to adapt or cope with changes, including nuanced data around access to supports.

Implications \& Applications: Provides data for planners, decision makers, and communities on what types of policies, programs, and other supports might lead to improved adaptive capacity for groups at the local level. An increased understanding of barriers or limitations to accessing exiting supports is key to increasing successful responses across community groups.

Insights: Numerous insights about how to increase adaptive
(Bennett et al. 2015)

(Knapp et al. 2014)

(McCubbin et al. 2015)

(Ruiz-Mallén et al. 2015) 

groups, document reviews, and Photovoice processes in order to understand flexibility and diversity, the ability to self-organize, social knowledge and learning, and access to assets. participatory approaches.

Attention to: Primarily social, as well as ability to proactively respond to ecological change.

Scale of Analysis: Household Individual community to multiple community.

Temporal Focus: Present capacity. Leads to abundant data. Differentiation of the factors that led to adaptive capacity to different changes - e.g., climate change, fisheries declines, and livelihood opportunities. Results are comprehensive, showing whether communities are able to adapt, cope or react. Produces lots of recommendations.

Weakness: Very time consuming and expensive. Difficult to confirm the

recommendations/outcomes with stakeholders. capacity to different changes that are occurring. Insights into some generic actions to build adaptive capacity e.g., improving relations, gender considerations, education. Research can provide insights into which factors

helped communities to adapt,

cope or react to changes that are occurring.

Implications \& Applications:

Suggests actions that

communities might take for

policies or programs that might

be implemented at higher levels to increase community adaptive capacity. No clear path to application of the results.
2009)

(McClanahan et al. 2009)

(Bennett et al. 2015)

(Bennett and

Dearden 2013)

(Cinner et al.

(Marshall et al. 2010)

(Marshall et al. 2013)

\section{Literature cited}

Aguilera, S. E., J. Cole, E. M. Finkbeiner, E. Le Cornu, N. C. Ban, M. H. Carr, J. E. Cinner, L. B. Crowder, S. Gelcich, C. C. Hicks, J. N. Kittinger, R. Martone, D. Malone, C. Pomeroy, R. M. Starr, S. Seram, R. Zuercher, and K. Broad. 2015. Managing Small-Scale Commercial Fisheries for Adaptive Capacity: Insights from Dynamic Social-Ecological Drivers of Change in Monterey Bay. PloS One 10(3):e0118992.

Alcorn, J. B., J. Bamba, S. Masiun, I. Natalia, and A. Royo. 2002. Keeping Ecological Resilience Afloat in Cross-Scale Turbulence: An Indigenous Social Movement Navigates Change in Indonesia. Pages 299-327. in F. Berkes, J. Colding, and C. Folke, editors. Navigating the Dynamics of Social-Ecological Systems. Cambridge, UK: Cambridge University Press.

Allison, E. H., A. L. Perry, M. C. Badjeck, W. Neil Adger, K. Brown, D. Conway, A. S. Halls, G. M. Pilling, J. D. Reynolds, N. L. Andrew, and N. K. Dulvy. 2009. Vulnerability of national economies to the impacts of climate change on fisheries. Fish and Fisheries 10(2):173-196.

Armitage, D. R., and R. Plummer. 2010. Adaptive Capacity and Environmental Governance.

Atleo, E. R. (Chief U. 2011. Principles of Tsawalk: An Indigenous Approach to Global Crisis. UBC Press, Vancouver, BC.

Ballard, H. L., and J. M. Belsky. 2010. Participatory action research and environmental learning: implications for resilient forests and communities. Environmental Education Research 16(5-6):611-627.

Barange, M., W. W. L. Cheung, G. Merino, and R. I. Perry. 2010. Modelling the potential impacts of climate change and human activities on the sustainability of marine 
resources. Current Opinion in Environmental Sustainability 2(5-6):326-333.

Barange, M., G. Merino, J. L. Blanchard, J. Scholtens, J. Harle, E. H. Allison, J. I. Allen, J. Holt, and S. Jennings. 2014. Impacts of climate change on marine ecosystem production in societies dependent on fisheries. Nature Climate Change 4(3):211-216.

Bennett, N. J., J. Blythe, S. Tyler, and N. C. Ban. 2015. Communities and change in the anthropocene: understanding social-ecological vulnerability and planning adaptations to multiple interacting exposures. Regional Environmental Change.

Bennett, N. J., and P. Dearden. 2013. A picture of change: using photovoice to explore social and environmental change in coastal communities on the Andaman Coast of Thailand. Local Environment 18(9):983-1001.

Berkes, F. 2012. Sacred Ecology: Traditional Ecological Knowledge and Resource Management. 3rd ed. Philadelphia, PA: Taylor and Francis.

Berkes, F., J. Colding, and C. Folke. 2000. Rediscovery of Traditional Ecological Knowledge as adaptive management. Ecological Applications 10(5):1251-1262.

Berkes, F., J. Colding, and C. Folke. 2003. Navigating social-ecological systems: building resilience for complexity and change. Cambridge, UK: Cambridge University Press.

Bernhardt, J. R., and H. M. Leslie. 2011. Resilience to Climate Change in Coastal Marine Ecosystems. Annual Review of Marine Science 5(1):120802113424002.

Blythe, J., M. Flaherty, and G. Murray. 2015. Vulnerability of coastal livelihoods to shrimp farming: Insights from Mozambique. Ambio 44(4):275-284.

Blythe, J. L. 2014. Resilience and social thresholds in small-scale fishing communities. Sustainability Science:157-165.

Blythe, J. L., G. Murray, and M. Flaherty. 2014. Strengthening threatened communities through adaptation: Insights from coastal Mozambique. Ecology and Society 19(2).

Brooks, N., W. N. Adger, and P. M. Kelly. 2005. The determinants of vulnerability and adaptive capacity at the national level and the implications for adaptation. Global Environmental Change 15(2):151-163.

Brown, H. C. P., J. N. Nkem, D. J. Sonwa, and Y. Bele. 2010. Institutional adaptive capacity and climate change response in the Congo Basin forests of Cameroon. Mitigation and Adaptation Strategies for Global Change 15:263-282.

Bundy, A., R. Chuenpagdee, S. R. Cooley, O. Defeo, B. Glaeser, P. Guillotreau, M. Isaacs, M. Mitsutaku, I. Perry, and R. I. Perry. 2015. A decision support tool for response to global change in marine systems: the IMBER-ADApT Framework. Fish and Fisheries:n/a-n/a.

Camilo Cardenas, J., and J. P. Carpenter. 2005. Three Themes on Field Experiments and Economic Development. Research in Experimental Economics 10:71-123.

Castillo, D., F. Bousquet, M. A. Janssen, K. Worrapimphong, and J. C. Cardenas. 2011. Context matters to explain field experiments: Results from Colombian and Thai fishing villages. Ecological Economics 70(9):1609-1620.

Cheung, W. W. L., R. D. Brodeur, T. A. Okey, and D. Pauly. 2015. Projecting future changes in distributions of pelagic fish species of Northeast Pacific shelf seas. Progress in Oceanography 130:19-31.

Cheung, W. W. L., J. L. Sarmiento, J. Dunne, T. L. Frölicher, V. W. Y. Lam, M. L. Deng Palomares, R. Watson, and D. Pauly. 2012. Shrinking of fishes exacerbates impacts of global ocean changes on marine ecosystems. Nature Climate Change 3(3):254-258.

Cheung, W. W. L., R. Watson, and D. Pauly. 2013. Signature of ocean warming in global fisheries catch. Nature 497(7449):365-8. 
Cinner, J. E., C. Folke, T. Daw, and C. C. Hicks. 2011. Responding to change: Using scenarios to understand how socioeconomic factors may influence amplifying or dampening exploitation feedbacks among Tanzanian fishers. Global Environmental Change 21(1):7-12.

Cinner, J. E., C. Huchery, E. S. Darling, A. T. Humphries, N. A. J. Graham, C. C. Hicks, N. Marshall, and T. R. McClanahan. 2013. Evaluating social and ecological vulnerability of coral reef fisheries to climate change. PloS One 8(9):e74321.

Cinner, J. E., C. Huchery, C. C. Hicks, T. M. Daw, N. Marshall, A. Wamukota, and E. H. Allison. 2015. Changes in adaptive capacity of Kenyan fishing communities. Nature Climate Change(June):1-6.

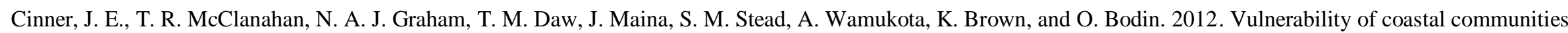
to key impacts of climate change on coral reef fisheries. Global Environmental Change 22(1):12-20.

Cinner, J., M. M. P. B. Fuentes, and H. Randriamahazo. 2009. Exploring Social Resilience in Madagascar's Marine Protected Areas. Ecology and Society 14(1):http://www.ecologyandsociety.org/ vol14/iss1/art41.

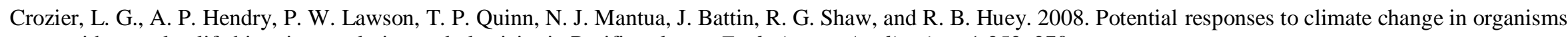
with complex life histories: evolution and plasticity in Pacific salmon. Evolutionary Applications 1:252-270.

Dietz, T., E. Ostrom, and P. C. Stern. 2003. The Struggle to Govern the Commons. Science 302(5652):1907-1912.

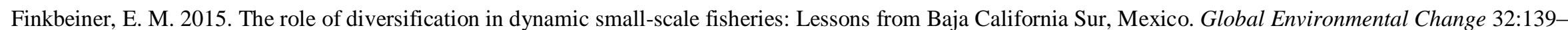
152.

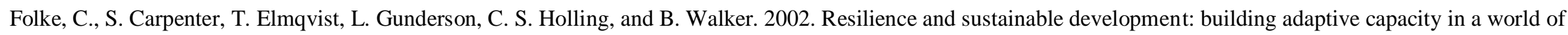
transformations. Ambio 31(5):437-440.

Ford, J., and D. Martinez. 2000. Traditional ecological knowledge, ecosystem science, and environmental management. Ecological Applications 10(5):1249-1250.

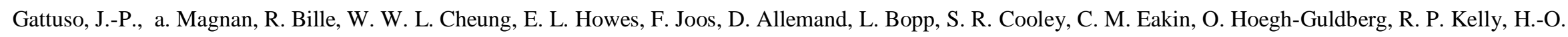
Portner, a. D. Rogers, J. M. Baxter, D. Laffoley, D. Osborn, a. Rankovic, J. Rochette, U. R. Sumaila, S. Treyer, and C. Turley. 2015. Contrasting futures for ocean and society from different anthropogenic CO2 emissions scenarios. Science 349(6243):aac4722-.

Gelcich, S., R. Guzman, C. Rodriguez-Sickert, J. C. Castilla, and J. C. Cardenas. 2013. Exploring External Validity of Common Pool Resource Experiments: Insights from Artisanal Benthic Fisheries in Chile. Ecology and Society 18(3):2.

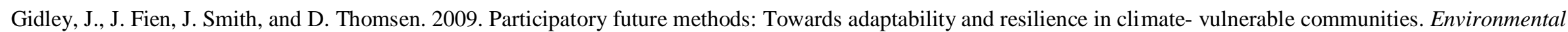
Policy and Goernance 19(6):427-440.

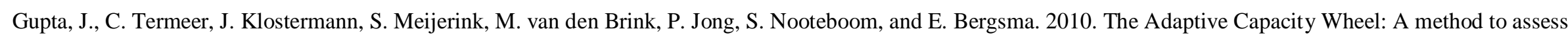
the inherent characteristics of institutions to enable the adaptive capacity of society. Environmental Science and Policy 13(6):459-471.

Himes-Cornell, A., and S. Kasperski. 2015. Assessing climate change vulnerability in Alaska's fishing communities. Fisheries Research 162:1-11.

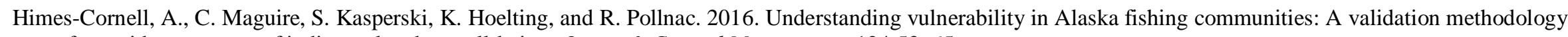
for rapid assessment of indices related to well-being. Ocean \& Coastal Management 124:53-65. 
Hughes, S., A. Yau, L. Max, N. Petrovic, F. Davenport, M. Marshall, T. R. McClanahan, E. H. Allison, and J. E. Cinner. 2012. A framework to assess national level vulnerability from the perspective of food security: The case of coral reef fisheries. Environmental Science and Policy 23:95-108.

Hutchings, J. A. 2011. Old wine in new bottles: reaction norms in salmonid fishes. Heredity:1-17.

Jensen, L. F., M. M. Hansen, C. Pertoldi, G. Holdensgaard, K.-L. D. Mensberg, and V. Loeschcke. 2008. Local adaptation in brown trout early life-history traits: implications for climate change adaptability. Proceedings of the Royal Society: B 275:2859-68.

Knapp, C. N., F. Stuart Chapin, G. P. Kofinas, N. Fresco, C. Carothers, and A. Craver. 2014. Parks, people, and change: The importance of multistakeholder engagement in adaptation planning for conserved areas. Ecology and Society 19(4).

Lam, V. W. Y., W. W. L. Cheung, and U. R. Sumaila. 2014. Marine capture fisheries in the Arctic: Winners or losers under climate change and ocean acidification? Fish and Fisheries:335-357.

Marshall, N. A., P. A. Marshall, J. Tamelander, D. Obura, D. Malleret-King, and J. E. Cinner. 2010. A Framework for Social Adaptation to Climate Change: Sustaining Tropical Coastal Communitites and Industries. Gland, Switzerland, IUCN.

Marshall, N. A., S. Park, S. M. Howden, a. B. Dowd, and E. S. Jakku. 2013. Climate change awareness is associated with enhanced adaptive capacity. Agricultural Systems 117:30-34.

McClanahan, T. R., J. E. Cinner, N. A. J. Graham, T. M. Daw, J. Maina, S. M. Stead, A. Wamukota, K. Brown, V. Venus, and N. V. C. Polunin. 2009. Identifying Reefs of Hope and Hopeful Actions: Contextualizing Environmental, Ecological, and Social Parameters to Respond Effectively to Climate Change. Conservation Biology 23(3):662-671.

McCubbin, S., B. Smit, and T. Pearce. 2015. Where does climate fit? Vulnerability to climate change in the context of multiple stressors in Funafuti, Tuvalu. Global Environmental Change 30(November 2014):43-55.

Menzies, C. R. 2006. Traditional Ecological Knowledge and Natural Resource Management. Lincoln, NE: University of Nebraska Press.

Miller, K., A. Charles, M. Barange, K. Brander, V. F. Gallucci, M. A. Gasalla, A. Khan, G. Munro, R. Murtugudde, R. E. Ommer, and R. I. Perry. 2010. Climate change, uncertainty, and resilient fisheries: Institutional responses through integrative science. Progress in Oceanography 87(1-4):338-346.

Munday, P. L., R. R. Warner, K. Monro, J. M. Pandolfi, and D. J. Marshall. 2013. Predicting evolutionary responses to climate change in the sea. Ecology Letters 16(12):1488-1500.

Muñoz, N. J., A. P. Farrell, J. W. Heath, and B. D. Neff. 2014. Adaptive potential of a Pacific salmon challenged by climate change. Nature Climate Change 5(February):163-166.

Pahl-Wostl, C. 2009. A conceptual framework for analysing adaptive capacity and multi-level learning processes in resource governance regimes. Global Environmental Change 19:354-365.

Pelling, M., C. High, J. Dearing, and D. Smith. 2008. Shadow spaces for social learning: A relational understanding of adaptive capacity to climate change within organisations. Environment and Planning A 40(4):867-884.

Perry, R. I., R. E. Ommer, M. Barange, S. Jentoft, B. Neis, and U. R. Sumaila. 2011. Marine social-ecological responses to environmental change and the impacts of 
globalization. Fish and Fisheries 12:427-450.

Reed, T. E., D. E. Schindler, M. J. Hague, D. A. Patterson, E. Meir, R. S. Waples, and S. G. Hinch. 2011. Time to evolve? Potential evolutionary responses of fraser river sockeye salmon to climate change and effects on persistence. PloS One 6(6):1-13.

Ruiz-Mallén, I., E. Corbera, D. Calvo-Boyero, and V. Reyes-García. 2015. Participatory scenarios to explore local adaptation to global change in biosphere reserves: Experiences from Bolivia and Mexico. Environmental Science and Policy 54:398-408.

Senos, R., F. Lake, N. J. Turner, and D. Martinez. 2006. Traditional Ecological Knowledge and Restoration Practice in the Pacific Northwest. Pages 393-426. in D. Apostol, editor. Encyclopedia for Restoration of Pacific Northwest Ecosystems. Washington, DC: Island Press.

Smit, B., and J. Wandel. 2006. Adaptation, adaptive capacity and vulnerability. Global Environmental Change 16:282-292.

Sumaila, U. R., W. W. L. Cheung, V. W. Y. Lam, D. Pauly, and S. Herrick. 2011. Climate change impacts on the biophysics and economics of world fisheries. Nature Climate Change 1(9):449-456.

Sunday, J. M., R. N. Crim, C. D. G. Harley, and M. W. Hart. 2011. Quantifying rates of evolutionary adaptation in response to ocean acidification. PLoS ONE 6(8):1-8. Tschakert, P., and K. A. Dietrich. 2010. Anticipatory learning for climate change adaptation and resilience. Ecology and Society 15(2):11.

Turner, N. J. 2014. Ancient Pathways, Ancestral Knowledge. McGill-Queen's University Press.

Whitney, C. K., S. G. Hinch, and D. A. Patterson. 2013. Provenance matters: Thermal reaction norms for embryo survival among sockeye salmon Oncorhynchus nerka populations. Journal of Fish Biology 82:1159-1176.

Yohe, G., and R. S. J. Tol. 2002. Indicators for social and economic coping capacity - moving toward a working definition of adaptive capacity. Global Env 12:25-40. 